\title{
THE TRANSFORMATION OF THE COLLECTIVE AGREEMENT IN SOVIET LAW*
}

\author{
MORRIS L. WEISBERg $\dagger$
}

Work in the USSR is a duty and a matter of honor for every able-bodied citizen, in accordance with the principle: "He who does not work, neither shall he eat."

The principle applied in the USSR is that of socialism: "From each according to his ability, to each according to his work."-ARTICLE I2, CONSTIXUTION OF THE UNION of Soviet Socialist RepUblics [I936].

$7 \mathrm{HE}$ collective agreement is a legal institution in nearly every in-

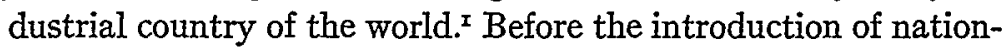
al-economic planning in the USSR, the Soviet collective agreement in theory and practice closely resembled agreements concluded in other countries between employers and trade unions, but under present conditions the agreement is characterized by one Soviet jurist as "an important weapon in the struggle for the plan." Thus, the development of the Soviet collective agreement offers a striking illustration of the transmutation of a legal institution resulting from changed politico-economic conditions. $^{3}$ It is this transformation in the legal nature of collective agreements in the Soviet Union which will be investigated.

\section{The Soviet Collective Agreement durdNg the New Econonic Policy and First Frve-Year Plan}

Although serfdom was abolished in I86I, industrialism came slowly to Tsarist Russia. In spite of legal prohibitions ${ }^{4}$ trade unions ${ }^{5}$ existed to a

* All Russian titles are translated in the footnote in which they first appear.

$\dagger$ Raymond Fellow, The Law School, University of Chicago.

I See the study of legislation on collective agreements of over three dozen countries, International Labour Office: Collective Agreements, Studies and Reports, Ser. A (Industrial Relations), No. 39 (1936).

= Dogadov, Etapy Razvitiya Sovetskogo Kollektionogo Dogovora [Stages in the Development of the Soviet Collective Agreement], 2 Izvestiya Akademii Nauk SSSR, Otdelenie Ekonomiki i Prava [News of the Academy of Sciences of the USSR, Section on Economics and Law] 83, 92 (r948).

3 Baykov, The Development of the Soviet Economic System (1947).

4 Articles 3r8-24 of Ulozhenie o Nakazaniyakh [Code of Punishments] and Article 124 of the Ugolovnoe Ulozhenie [Criminal Code], Svod Zakonov [Collection of Laws], vol. XV. Gromov, Zakony Ugolovnye [Criminal Laws] $x_{55}, 805$ (IgI3).

5 From the beginning Soviet trade unions have been organized along industrial rather than craft lines, so that all workers and employees in a particular enterprise belong to a single union. 
limited extent as organs of social revolution. Poor labor conditions ${ }^{6}$ often led to spontaneous walkouts and demonstrations by workers which were major factors leading to improvements in labor conditions. ${ }^{7}$ But not until the October Revolution in I9I7 were collective agreements concluded generally. In the first months after the Revolution, collective agreements were used in enterprises still not nationalized to establish labor conditions, particularly wages. A decree of July 2, I9I8 extended the use of the collective agreement to the nationalized sector of the economy.

In December r9r8 at the beginning of the era of War-Communism, the first KZoT (Code of Laws on Labor) ${ }^{8}$ of the RSFSR (Russian Soviet Federative Socialist Republic) was enacted. War-Communism (IgI8I920) was a period of workers' control over enterprises and attempted nationalization of all industries. The $\mathrm{KZOT}$ provided that in all enterprises labor conditions and particularly wages were to be regulated by collective agreements. These agreements were drawn up by trade unions with participation by the manager or owner in industries still not nationalized, and submitted for "confirmation"' by the NKT" (People's Commissariat of Labor). Collective agreements during this period were really normative acts of the government since the participation of the manager or owner was permissive and agreements had to be approved by the NKT in any case. During the latter stage of War-Communism, collective agreements were replaced by centralized governmental control of all labor conditions.

\section{THE NEP (NEW ECONONIC POLICX, I92I-27)}

The confused period of War-Communism ended on March 2I, I92I with the announcement by Lenin of his "New Economic Policy" at the Tenth Communist Party Congress. The NEP was a return to a dichotomous economy, part privately-owned and part nationalized, a retreat made possible only by Lenin's great prestige. The government continued to control

${ }^{6}$ Until October $19 \mathrm{I} 7$ the Ustav o promyshlennom trude [Code of Regulations on Industrial Labor] was effective. Aleksandrov and Moskalenko, Sovetskoe Trudovoe Pravo, Uchebnik Dlya Yuridicheskikh Shkol, 2-e Izdanie, Vsesoyuznyi Institut Yuridicheskikh Nauk Ministerstva Yustitsii SSSR [Soviet Labor Law, Textbook for Juridical Schools, 2d ed., All-Union Institute of Juridical Sciences of the Ministry of Justice of the USSR] (hereafter, Aleksandrov, Sovetskoe Trudovoe Pravo) 4I-42 (I947).

7 Labor unrest in $x 897$ led to the enactment of a law fixing eleven and one-half hours as the maximum working day in factories. Hubbard, Soviet Labour and Industry $x 7$ et seq. (I942). This was Article $x 96$ of the Code of Regulations on Industrial Labor. Article 74 covered an eight-hour working day only for minors from twelve to fifteen years of age.

8 This code established a duty to work for all able-bodied citizens from the ages of sixteen to fifty. KZoT Art. 2 (Igr8). See Gorshenin, Pervyi Sovetskii Kodeks Zakonov o Trude [The First Soviet Code of Laws on Labor], 2-3 Sovetskaya Yustitsiya [Soviet Justice] 27 (1938).

9 KZoT RSFSR Art. 8 (rgr8).

so Narodnyi Kommissariat Truda. 
major industry, banking, foreign trade--"the commanding heights of the economy." In the nationalized sector enterprises were put on an accounting basis and expected to be run at a profit; planning was introduced in a rudimentary form. In I922 the second KZoT of the RSFSR ${ }^{\text {II }}$ was promulgated to meet the needs of an economy in which freedom of trade and privately-owned industry were allowed within limits fixed by legislation. This code set forth the minimum labor guarantees in both the national and private sectors of the economy with specific labor conditions left to be determined by collective agreement.

I. Collective agreements as a source of law.-The structure of the collective agreement in other legal systems supplies a frame of reference with which to compare the Soviet collective agreement during the NEP. In collective agreements of all legal systems two fundamental sets of regulations may be distinguished, which will be referred to as the normative and relational parts. ${ }^{x 2}$ The relational part contains provisions which define the rights and obligations of the parties signatory to the agreement-one or more employers or organizations of employers, and one or more labor organizations. ${ }^{\text {I3 }}$ The normative part regulates the labor conditions of work-

Ix The KZoT RSFSR is divided into the following chapters: I General part, II The method of engagement and dismissal of working forces, III The method of calling up citizens of the RSFSR for compulsory labor service, IV Collective agreements, V The employment contract, VI Rules of employment, VII Standards of output, VIII Remuneration for work, IX Guarantees and compensation, X Working time, XI Rest periods, XII Apprenticeship, XIII Work of women and minors, XIV Protection of labor, XV Trade (productive) unions of workers and employees and their representatives in enterprises, agencies and businesses, XVI The settlement of labor disputes and investigation of cases of the violations of labor legislation, XVII Social insurance. A translation of the KZoT RSFSR of 1922 is found in International Labour Office, Legislative Series, Vol. XVII-I936, Pt. II, at I387 (I936) and in A Selection of Documents Relative to the Labour Legislation in Force in the Union of Soviet Socialist Republics, Presented by the Secretary of State for Foreign Affairs to Parliament by Command of His Majesty (r93 I) (contained in Accounts and Papers: Twenty Volumes, Vol. XXXIV [I930-3I]). Later federal and RSFSR decrees have made major portions of the KZoT RSFSR obsolete. See Golyakov, Zakonodatel'stvo o Trude, Kommentarii Zakonodatel'stvy o Trude SSSR i Kodeksy Zakonov o Trude RSFSR, Vsesoyuznyi Institut Yuridicheskikh Nauk Ministerstva Yustitsii SSSR [Legislation on Labor, Commentary on the Legislation on Labor of the USSR and the Code of Laws on Labor of the RSFSR, All-Union Institute of Juridical Sciences of the Ministry of Justice of the USSR] (hereafter, Golyakov, Zakonodatel'stvo o Trude) (r947).

12 With the exception of the German National Labor Act of 20 January 1934, which prescribed that collective rules be issued by the labor trustees on their own motion. International Labour Office, op. cit. supra n. I, at I 24 et seq. For an excellent study of the German collective agreement prior to this act, see Fuchs, Collective Labor Agreements in German Law, I5 St. Louis L. Rev. $x$ (I929). Fuchs calls the separation of provisions in German collective agreements into normative and relational ["obligatory" in German Law] "a master stroke upon which the usefulness and symmetry of the whole structure of collective agreement law depend." Ibid., at 40-4I. See also Pouillot, Collective Labour Agreements in France, 37 Int. Labour Rev. I, 2 (1938).

${ }_{3}$ The relational part contains any provisions which the parties consider appropriate for successful functioning of the agreement, such as terms covering organization of the relations between the parties (submission to arbitration of collective disputes), collective relations between the parties (preference to union members in hiring, seniority), joint bodies (adminis- 
ers who are not parties themselves. ${ }^{\mathrm{I}}$

The normative and relational parts of the collective agreement must be kept distinct. ${ }^{5}$ Although the relational part may vary with legal systems, it is contractual in nature where the conclusion of agreements is entirely voluntary. Insofar as they are enforceable at all, the rights and obligations involved are those which arise out of the ordinary law of contracts. On the other hand the normative part remains the same in most legal systems. It establishes labor conditions which enter automatically into every contract of employment of the individual worker with his employer. The normative part functions in the same way as protective labor legislation. It might be said that the state has delegated a legislative function to the parties which draft and sign the collective agreement. The parties by their own agreement have the power to establish legal norms (rules) which, like legislative norms, ${ }^{\text {I6 }}$ restrict the area of contractual freedom of workers and employers

tration of pension funds), and collective engagement or dismissal of workers (maintenance of ratio of women to men, etc.). International Labour Office, op. cit. supra note I, at $14 \mathrm{I}$ et seq.

${ }^{2}$ The normative part contains provisions subject to incorporation in an individual contract of employment between a worker and his employer: for example, terms relating to the employer's obligations (wages, hours, vacations, etc.), the worker's obligations (good faith performance, etc.), the termination of the contract of employment (notice period), the organization of individual relationships between employer and worker (fines), or the settlement of grievances and other individual labor disputes. Ibid., at I40-4I.

${ }^{25}$ "The two sets of clauses are of course closely bound up with each other and may also impose obligations simultaneously on the parties to a collective agreement and the parties to individual contracts of employment. It is then a matter for the courts to decide in each particular case whether the person (or body) to whom a certain right (or obligation) applies is the individual employer or worker, or the contracting organisation, or both at once." Ibid., at I38.

${ }^{6} 6$ To paraphrase Maine's observation, the history of the collective agreement in the United States during the last half-century has been one of confusion between status and contract. Gregory and Katz, Labor Law: Cases, Materials and Comments, II 52 et seq. (1948); Witmer, Collective Labor Agreements in the Courts, 48 Yale L.J. 195 (1938). The problem has been framed broadly in terms of whether the collective agreement, with no mention of the distinction between its relational and normative parts, is a "contract." In order to give effect to the normative part, legal thinking resorted quite naturally to the conceptualism of agency. The union was regarded as the agent of its members who became entitled to rights and subject to obligations. This treatment created difficulties since courts found themselves confronted with questions of the juristic personality of unions and of consideration for the "contract." The agency notion did not allow non-union employees to be covered by collective agreements, and it complicated the enforcement of the relational part since an agent cannot acquire rights or duties for himself. Other traditional concepts were employed. The wage clauses of collective agreements were given effect under the "usage and custom" theory of commercial law. When the employee knew of the provisions of the collective agreement, he could be said to have bargained out for them with his employer as a part of his employment contract. Still other courts adopted a "third-party beneficiary" theory, under which it was assumed that the collective agreement was a contract between the parties for the benefit of employees as third parties. This theory, which has the unique distinction of considering the collective agreement as a contract in order to allow the normative part to operate as a source of law, comes close, however, to recognizing that the union and employer have done something by their collective agreement which automatically affects the labor conditions of individual workers. The Su- 
in concluding contracts of employment. Collective agreements, together with labor legislation, are sources of labor law..$^{x 7}$

2. Normative and relational parts of NEP collective agreements.-The I922 KZoT of the RSFSR defined the collective agreement as:

... an agreement concluded between a trade union ... as the representative of the workers and employees on the one hand, and an employer on the other hand, which fixes the conditions of labor and employment for individual enterprises, agencies and businesses or groups thereof .... and which specifies the contents of future individual contracts of employment or work. ${ }^{.8}$

This definition indicates clearly that the Soviet collective agreement was to function as a source of law. Employment contracts could not depart from the provisions of the normative part of the agreement, at least not to the detriment of the worker. ${ }^{x}$ Such a prohibition had a dual effect. Terms of contracts of employment concluded by workers covered by a collective agreement were ineffective insofar as they did not conform to provisions of the collective agreement. Secondly, terms of contracts of employment which violated the collective agreement were automatically replaced by the provisions of the agreement. The KZoT of the RSFSR also

preme Court in J. I. Case Co. v. NLRB, 32I U.S. 332, 334 (I944), showed a recognition of the function of the normative part: "The negotiations between union and management result in what often has been called a trade agreement, rather than in a contract of employment. Without pushing the analogy too far, the agreement may be likened to the tariffs established by a carrier, to standard provisions prescribed by supervising authorities for insurance policies, or to utility schedules of rates and rules of service, which do not of themselves establish any relationships but which do govern the terms of the shipper or insurer or customer relationship whenever and with whomever it may be established." See Weygand, The Majority Rule in Collective Bargaining, 45 Col. L. Rev. 556 (x947). The nature of the normative and relational parts is being seen more clearly today. Compare Lenhoff, The Present Status of Collective Contracts in the American Legal System, 39 Mich. L. Rev. Irog (I94I); Braun, The Dual Nature of Collective Agreements, 5 I J. Pol. Econ. 45I (I943), which deals with problems of the normative part under the Wagner Act. The time has come for American law-men to stop repeating Duguit's observation of thirty years ago with reference to French law: "The truth is that although collective labor contracts have multiplied . . . the time has not yet come for legislative action. We have here an institution which is still in the process of formation and is far from complete development." Duguit, Collective Acts as Distinguished from Contracts, 27 Yale L.J. 753, 866 (r9I8). The formulation of the relational part as contractual in American law may not be the last word, however. See Chamberlain, Collective Bargaining and the Concept of Contract, 48 Col. L. Rev. 829, 847 (r948), and Llewellyn, What Price ContractAn Essay in Perspective, 40 Yale L.J. 704, 736-37 (I93I).

r7 Compare Kelsen, General Theory of Law and State $1_{42}$ (1945).

${ }^{18} \mathrm{KZOT}$ RSFSR Art. 15.

19 KZoT RSFSR Art. 28: "The provisions of the contract of employment are defined by agreement of the parties. Provisions of the contract of employment are ineffective which worsen the situation of workers in comparison with provisions established by legislation on labor, the provisions of a collective agreement, and the rules of employment effective in a particular enterprise or agency ... and also provisions which tend to limit the political and general civil rights of workers." 
provided for extension of the normative provisions of the collective agreement to non-union workers. ${ }^{20}$ Employers could not force workers to sign individual contracts of employment containing waivers of rights secured for them under collective agreements. Collective agreements or contracts of employment could deviate from the KZoT or other legislation only in the direction of improving the conditions of workers. Terms of the collective agreement which were less favorable to workers than the provisions of the KZoT or labor legislation were treated as void. ${ }^{21}$ These various provisions are typical of other legal systems as well. ${ }^{22}$

Soviet law during the NEP treated the norms established by the collective agreement like legislative norms. If an employer paid wages less than those stipulated in the agreement a worker could assert a claim. Moreover, in addition to punishing employers who violated labor legislation, ${ }^{23}$ the Criminal Code of the RSFSR established criminal responsibility for employers who violated collective agreements in "bad faith."

${ }^{20} \mathrm{KZ}$ oT RSFSR Art. r6: "The provisions of the collective agreement extend to all persons working in a particular enterprise or agency, irrespective of whether they are members of the trade union which has concluded the agreement. Note: The effect of the collective agreement does not extend to persons of the managing staff, who exercise the right of engagement and dismissal."

${ }^{2 x}$ KZoT RSFSR Art. 4: "Every contract or agreement which is less favorable regarding labor conditions than the provisions of this Code shall be void." Art. I9: "Provisions in collective agreements which specify labor conditions less favorable than those in effect under this Code and other legislative provisions and orders shall be void." Art. 52: "Rules of employment shall not be contrary to labor legislation or decrees or to any collective agreement which may be in force in the enterprise or agency in question." For rules of employment see text infra p. 445 .

2 International Labour Office, op. cit. supra note I, at I25 et seq.

${ }^{23}$ Ugolovnyi Kodeks [Criminal Code] (hereafter, UK), RSFSR Art. I33.

24 UK RSFSR Art. I34: "A violation by an employer of collective agreements concluded with a trade union, of wage agreements, and settlements of arbitration boards, if in the course of the judicial or arbitral proceeding it has been established that the violation was in bad faith ..." is punishable by corrective labor for a period up to six months or fine up to three hundred rubles, or if the violation concerns a group of not less than three workers, deprivation of freedom or corrective labor for a period up to one year or fine up to ten thousand rubles. "The crimes covered by Article 134 are characterized by the following two features. First, the violation in bad faith of collective agreements and [wage] agreements; bad faith consists of intentional violation. The second feature bears a formal character-bad faith must be preliminarily established in the judicial or arbitral proceeding. Preliminary judicial determination of bad faith means that institution of criminal prosecution according to Article ${ }_{34}$ of the UK may take place only if in decision of a labor case in a civil proceeding there is disclosed the bad faith character of the violation of the collective agreement or wage agreement. Preliminary establishment of bad faith (in a judicial or arbitral proceeding) leads to institution of a criminal prosecution, but does not bind the court, which later decides that issue, and consequently the court, deciding the criminal case according to Article $\mathrm{r} 34$ of the Criminal Code, decides it independently, according to the combination of all the circumstances of the case, and may either recognize bad faith or reject its presence." Roginskii and Karnitskii, Ugolovnyi Kodeks [Criminal Code] RSFSR 20I (r936). Article ro of the UK RSFSR is applicable to all crimes and defines mens rea in the Soviet criminal law: "Persons who commit socially dangerous acts shall be liable to the application of measures of social defense of a judicial-correctional char- 
The relationship between collective agreements and labor legislation generally was as follows: Collective agreements first of all dealt with questions which were not covered by legislation such as wages. ${ }^{25}$ The wage provisions of collective agreements determined the exact amounts above the minimum established by governmental enactments for the various categories of workers. Second, the collective agreement supplemented legislative provisions concerning safety devices, industrial hygiene and the like. Finally, collective agreements in some instances deviated from legislation in the direction of improving labor conditions. ${ }^{26}$

The normative part of the collective agreement functioned as an important source of law, regulating a wide variety of labor conditions. In addition to the question of wages, it regulated standards of output, ${ }^{27}$ working hours and rest periods, protection of the life and health of workers, safety technique, industrial sanitation and hygiene, and apprenticeships. The relational part of the collective agreement during the NEP

acter only: a) if they acted intentionally, i.e., if they foresaw the socially dangerous consequences of their acts, or desired those consequences, or knowingly allowed them to happen, or b) if they acted carelessly, i.e., they did not foresee the consequences of their acts although they ought to have foreseen them, or if they fool-heartedly hoped to avert such consequences." (Italics added.)

"Not every violation of the collective agreement constitutes the crime covered by Article I34, but only violations in bad faith. An explanation of the Supreme Court of the RSFSR of $x 9$ April $x_{927}$ indicates that "to the concept of "bad faith violations" one must refer not only cases of intentional, direct violation of collective agreements, wage agreements and settlements of arbitral boards, but also those cases where for the fulfilment of these agreements as a whole or in any part of the employer knowingly did not take all possible measures.' This may be understood only in the sense that 'bad faith' must be found where the employer 'knowingly allows' (UK Art. ro) violation of the agreement to the harm of workers, i.e., also where there is eventual intent." Trainin, Ugolovnoe Pravo, Osobennaya Chast', Dolzhnostnye i Khozyaistvennye Prestupleniya, Vsesoyuznyi Institut Yuridicheskikh Nauk [Criminal Law, Special Part, Official and Economic Crimes, All-Union Institute of Juridical Sciences] 133 (I938).

${ }^{25}$ KZoT RSFSR Art. 58: "The amount of the employee's remuneration for his work shall be fixed by collective agreement and employment contract." Art. 59: "The amount of the remuneration shall not be less than the compulsory minimum wage fixed for a given period by the competent state authorities for the category of work in question."

${ }^{26}$ Dogadov, op. cit. supra note 2 , at 85 , states that such deviations were rare, and mentions the instance of lengthening the period of time of temporary incapacity, which would give the management the right to dismiss a worker. According to Article I $_{5}$ of the collective agreement concluded in 1928 by the Leningrad Provincial-Committee of the Union of metal-workers with the Joint Stock Company Medsnabtorgprom, in case of absence from work on account of temporary loss of working capacity, lasting more than four months, the worker might be dismissed without payment of a leaving grant (Article 89 of the KZoT RSFSR provides for payment of two-weeks earnings in certain cases). The two-month period of the KZoT was lengthened in the collective agreement to four months.

${ }^{27}$ KZOT RSFSR Art. 56: "Standards of output shall be fixed by the management of the enterprise or agency in agreement with the trade union or the competent officials of the trade union." Standards of output today are determined on the basis of the Decree of the SNK (Council of People's Commissars) of the USSR, $x_{4}$ January 1939. See note I48 infra. 
covered subjects typically covered by collective agreements in other legal systems: the obligations of employers to provide funds for the maintenance of the factory-committee, the manner of hiring and dismissal of workers and employees, the method of review of labor disputes. ${ }^{28}$ Most of these provisions in the normative and relational parts were later supplanted by legislation.

3. Conclusion, registration, disputes.-Collective agreements were concluded in a centralized manner by higher economic and trade-union organizations. According to the KZoT of the RSFSR, collective agreements might be either general or local. ${ }^{29}$ Where general collective agreements were concluded, local agreements could be made only where permitted in the general agreement.

As in many other legal systems ${ }^{30}$ the collective agreement had to be concluded in writing, registered, and promulgated in order to acquire legal effect. During the NEP collective agreements were registered by the representative of the People's Commissariat of Labor (NKT), unless that agency exercised its power to annul any part of the agreement less favorable to workers than existing labor legislation. Thereafter, with the consent of both parties, the remainder of the agreement could be registered. ${ }^{3 x}$ After registration the collective agreement came into effect on the date of signature by both parties or on the date specified in the agreement itself. ${ }^{32}$ Disputes between employers and workers based on an unregistered agreement were settled in accordance with general labor legislation. ${ }^{33}$ Appraisement and Disputes Commissions (RKK) were set up by the KZoT of the RSFSR to supervise directly the carrying out of the collective agreement. ${ }^{34}$

Legislation did not make the conclusion of a collective agreement compulsory. As far as the nationalized sector of the economy was concerned the question was academic, for Communist-led trade unions would strike only in cases of extreme mismanagement. Disputes which arose between the parties in the conclusion of collective agreements were referred to the

${ }^{28}$ Pasherstnik, Voprosy Kollektionogo Dogovora v. SSSR [Questions concerning the Collective Agreement in the USSR], 4 Sovetskoe Gosudarstvo i Pravo [Soviet State and Law] 38, 42 (1948).

${ }^{29} \mathrm{KZoT}$ RSFSR Art. I 7: "Collective agreements may be general (covering within a republic a whole branch of industry, branch of the national economy or administration) or regional (local). In any case where a general collective agreement exists, the conclusion of local collective agreements shall be permitted only in the cases and in the manner specified in the general collective agreement."

30 International Labour Office, op. cit. supra note I, at 122-23.

${ }^{3 x}$ KZoT RSFSR Art. $21 . \quad 32$ Ibid., Art. $22 . \quad 33$ Ibid., Art. 25.

34 Ibid., Art. 27; Setllement of Labor Dispates, text infra p. 475 . 
proper organizations with a provision for compulsory arbitration..$^{35}$ On the other hand, the refusal of a private employer to conclude a collective agreement might lead to a strike on the part of the union. The KZoT provided, however, that trade unions were not financially responsible under collective agreements, ${ }^{36}$ and in particular a private employer could not claim damages caused by a strike while a collective agreement was in force.

4. The class struggle and economic struggle during the NEP.-The $\mathrm{KZOT}$ of the RSFSR defined the collective agreement as one concluded between workers and "employers." Employers during the NEP were either the state or private individuals. Trade unions in the private sector exercised their traditional Marxist functions of protecting workers from "capitalistic exploitation." At first the "class struggle" was also announced as policy in the nationalized sector, ${ }^{37}$ but later the efforts of trade unions were directed toward the "economic struggle," which consisted of an emphasis on correcting the "bureaucratic" abuses of management and increasing the productivity of labor. Trade union leaders had to decide whether to aid the government's policy of increasing productivity with a theoretical long-run benefit to the workers, or to serve the interests of the workers more directly by continuing to demand higher wages from the state as the most important employer of labor. Trade union leaders such as Tomski adopted the latter course and in effect carried the class struggle over into the nationalized sector. Tomski and his followers were accused ${ }^{38}$ of a narrow "trade-unionist" line which sacrificed the interests of the country as a whole for the sake of labor alone. As a result Tomski retired in I929 and was replaced by Kaganovich.

This condemnation of a "trade union" movement coincided with the victory of the Stalin faction over Trotsky and the decision to "build socialism in one country." The mesalliance of capitalism and socialism which existed during the NEP came to an end with the Fifteenth Communist Party Congress in December I927. Private enterprise was in effect completely eliminated, the state became practically the sole employer of labor, and any class-struggle within the socialist economy became unthinkable.

35 Ibid., Art. I72. ${ }^{36}$ Ibid., Art. 20.

37 Compare Lenin's statement in I920: "Our present government is such that the proletariat, organized to the last man, must protect itself against it. And we must use the workers' organization for the protection of the workers against their Government." Hubbard, op. cit. supra note 7 , at $15 \mathrm{I}-52$.

${ }^{38}$ Resolution of the XVI Congress of the VKP(b) On the Tasks of Trade Unions in the Reconstruction Period, Essen and Allaverdova, VKP(b) o Profsoyuzakh [The VKP(b) on Trade Unions] I2I et seq. (I933). 
Under the new leadership of Kaganovich the function of trade unions was to increase production on every front. Workers were to be convinced that they own the means of production and that higher wages do not come out of the "profits" of an enterpreneur. Therefore the Soviet worker should be interested in a general increase of national production. In a climate involving all the esprit of war, the first five-year plan was begun. Workers were called upon for great sacrifices, for increased productivity in spite of privations; consumer goods were postponed to a later fiveyear plan.

THE FIRST FIVE-YEAR PIAN (I928-32)

With the introduction of state planning in 1928 , the national-economic plan began to regulate all economic life in the USSR. The plan determined not only the quantity and kinds of production but also the level of prices and wages. The operation of each Soviet enterprise was based on the promfinplan ${ }^{39}$ (industrial-financial plan) fixed for that enterprise.

National-economic planning also introduced the principle of "democratic centralism." ${ }^{\circ}$ By this the Soviet jurist means centralization of control but decentralization of operation. In the area of the collective agreement democratic centralism manifested itself in two directions: the method of concluding collective agreements was decentralized and the regulation of labor conditions by centralized control led to the decline of the collective agreement as a source of law.

39 "The plan of an individual industrial enterprise is called the promfinplan (industrialfinancial plan). It embraces both production as well as financial-economic indices of the work of the enterprise. The same plan in the sphere of transportation is designated the tranfinplan; in the sphere of trade, the torgfinplan; in the sphere of construction, the siroifinplan, etc. The development of planning during recent years has produced a new and exceedingly important form of planning - the tekhpromfinplan. The most important aspect of the tekhpromfinplan is that on the basis of mobilizing the activity of the toiling masses, it not only gives indices (tasks) for the work of the whole plant and each of its parts, but also the technical basis of these indices-tasks." Rubinshtein, Sovetskoe Khozyaistvennoe i Grazhdanskoe Pravo [Soviet Economic and Civil Law] 78 (2d ed., 1938).

40 "In democratic centralism, as an organizational, and therefore a universal principle of the Soviet state, all other principles of Soviet state administration find their generalization and expression. This principle consists of two parts: centralism and democratism. Centralism means the subjection of the part to the whole, of lower organs of the state to higher organs. In the Soviet state such subjection is needed for several reasons It is necessary first, because the USSR is encircled by capitalistic enemies, which requires the unification of all forces of the nation for the possible checking of an aggressor. Secondly, it is based on the very nature of the socialist economy, which is unthinkable without centralized planning and direction. Finally, it is dictated by the very nature of Soviet power, international in its nature, able to unite into a single centralized state the toilers of different nations." Institut Prava Akademii Nauk SSSR, Osnovy Sovetskogo Gosudarstva i Prava [Institute of Law of the Academy of Sciences of the USSR, Bases of the Soviet State and Law] (hereafter, Osnovy Sovetskogo Gosudarstva i Prava) 238 (I947). This textbook presenting thefundamentals of juridical science, describes it as "one of the social sciences, closely related to other social sciences, such as philosophy, political economy, history." Ibid., at 3 . 
I. Decentralization of conclusion of collective agreements.-Until I930 collective agreements were concluded by territorial organs of the union, ${ }^{4 \mathrm{I}}$ according to the provisions of the KZoT of the RSFSR covering general and local agreements. In the absence of any broad experience in planning, the local collective agreement was used to achieve flexibility. The old system of general and local agreements, however, did not provide for the needs and resources of lower echelons of trade-union and economic organizations. In I930 a joint decree of the VTsSPS (All-Union Central Council of Trade Unions) and the Supreme Economic Council ordered collective agreements to be concluded between the management of the enterprise and the factory committee of the trade union instead of higher economic and trade union organizations..$^{42}$ Collective agreements were concluded, however, on the basis of limits defined by higher economic and trade union organizations in conformity with the national-economic plan. The management and factory committee can adjust these limits in conformity with the requirements and resources of the enterprise, except that no adjustment of the lowest wage category is possible. ${ }^{43}$

2. Decline of the collective agreement as a source of law.-Concomitantly with the decentralization of the method of concluding collective agreements, more and more labor conditions became subject to centralized governmental regulation. ${ }^{44}$ At the end of 1925 regulation of wages was

${ }_{4 \pi}$ For example, the raikom (raionnyi komitet, regional committee), gorkom (gorodskoi komitet, city committee), obkom (oblastnoi komitet, provincial committee), TsK (tsentral'nyi komitet, central committee) are included in this group, but lower level union organizations such as the FZK (fabzavkom, fabrichno-zavodskoi komitet, factory-committee), mestkom (mesinyi komitet, local committee, the equivalent of the factory-committee in agencies) are not.

${ }^{2} \mathrm{~A}$ decree of the Presidium of the VTsSPS, 8 August 1930, stated that new tasks and conditions "raise sharply the question of the necessity of change in existing practice in the direction of a transition from centralized-general-collective agreements to regional (raion) and, where possible, to local (plant) collective agreements. ... In addition the strengthening of the plan principle in the national economy of the USSR demands a more centralized regulation of the basic questions of collective agreements-productivity of labor, payments, the establishment of standards, etc. Therefore, together with giving the right to local organizations to conclude collective agreements, it is considered necessary that the TsK [central committees] of unions in directives signed jointly by economic-organs and binding locally define the basic conditions of the agreements." Trud [Labor] 23 August $193^{\circ}$.

43 Decree of the SNK (Council of People's Commissars) of the USSR, 4 June x938. See text infra p. 555 .

${ }_{44}$ "The success of the socialist forms of economy in the city and country, the thorough reconstruction and restoration of Soviet enterprises, the radical improvement in sanitation and labor conditions, strengthened by means of legislation, the enormous growth of wages together with the broad introduction and strengthening of planning principles in the national economy, the task of preserving a firm state, wage and financial discipline-all this led to the intensification of centralized state regulation of labor conditions, with the strict observance of the relations and proportions established by the national-economic plan. In the periods of socialist industrialization of the country and collectivization of agriculture, conditions established by legislation on labor, as a rule were not subject to change by means of agreement. In 
introduced for employees in agencies under state or local budgets. ${ }^{45}$ In I929 such regulation was extended to employees of credit, state and social insurance agencies, and to the managerial staffs of trusts..$^{46}$ In I933 state regulation of wages was initiated for workers and technical personnel, in the coal47 and rail industries, ${ }^{48}$ and other important branches of the national economy. Finally, compensation of workers and employees in all state enterprises and agencies became subject to state regulation. A decree of the Council of People's Commissars of June 4, I938 prohibits Ministers and central agencies of the USSR, and also Councils of Ministers of the Union-Republics from introducing new wage scales, wage rates, official salaries, wage-qualification handbooks, or essential revisions in the standards of output or appraisement without authorization of the Council of Ministers of the USSR.49

With the practical elimination of the normative part of the collective agreement during national-economic planning, wages, hours, standards of output, and labor protection came to be regulated by governmental decrees. The collective agreement had ceased to function as an important source of law..$^{50}$

those periods general norms, defining labor conditions, occupied a place in the collective agreement only insofar as they referred to questions which had not been regulated by legislation. The basic significance of the collective agreement in those periods was its existence as a most important economico-political bilateral obligation, mobilizing the masses for the fulfilment and overfulfillment of production plans, for the improvement of the organization of labor, for improving the material and cultural standards of living of workers and employees in conformity with the policy of the party and government, in conformity with legislation of the Soviet State. The obligational side of the collective agreement became predominant, directed toward the achievement of the basic tasks of the socialist enterprise, imposed by the state plan." Pasherstnik, op. cit. supra note 28 , at $42-43$.

${ }_{43}$ Decree of the SNK of the USSR, 9 June 1925, SZ USSR [1925] No. 42, Art. 321. SZ USSR is the abbreviation of Sobranie zakonov i rasporyazhenii Raboche-krest'yanskogo Pravitel'stva Soyuza SSR [Collection of laws and orders of the Worker-peasant Government of the USSR], the official compilation before $x_{93} 8$.

${ }^{4}$ Decree of the SNK of the USSR, 7 December 1929, SZ USSR [1929] No. 76, Art. 737.

17 Decree of the SNK of the USSR and TsK VKP(b), 2I May 1933, SZ USSR [I933] No. 3I, Art. 183. This covered workers in the Don Basin.

$4^{8}$ Decree of the SNK of the USSR and TsK VKP(b), 8 July r933, SZ USSR [I933] No. 4I, Art. 242.

49 Decree of the SNK of the USSR, 4 June 1938 , SP USSR [r938] No. 27 , Art. r78. SP USSR is abbreviation of Sobranie postanovlenii i rasporyazhenii Pravitel'stva Soyuza SSR [Collection of decrees and orders of the Government of the USSR], the official compilation after 1938; from April r946-Sobranie postanovlenii i rasporyazhenii Soveta Ministrov SSSR [Collection of decrees and orders of the Council of Ministers of the USSR].

5o Typical provisions of the collective agreement between the management of the plant and the plant-committee of the Truck building plant Yegorov for I93r, exemplifying the decline of the normative part, indicated that special clothing should be distributed according to the provisions set up by the NKT USSR, published in r929; the decree of the NKT, II December 
To compensate trade unions for this loss of function the NKT was assimilated into the VTsSPS ${ }^{\text {sx }}$ (All-Union Central Council of Trade Unions) in I933 and the Soviet trade-union system became part of the governmental structure itself. ${ }^{52}$ Trade unions took over administration of social insurance, inspection of labor and labor protection. The VTsSPS was given the right in addition to report on plans dealing with wage funds and labor productivity established by Gosplan. (State Planning Commission) in the Council of Ministers of the USSR.53

Collective agreements concluded in 1933 were extended during I934. In I935 they were renewed only in certain branches of the economy (water transportation, trade, lumbering). Collective agreements concluded in earlier periods were enforceable, but only insofar as their provisions did not conflict with later legislation and governmental decrees. ${ }^{54}$

\section{The New Soviet JuRISPRUdence}

The fact that new collective agreements were not concluded after I934 $_{9}$ reflected a controversy then raging in Soviet legal theory. One school of thought led by Pashukanis expected that law itself would disappear after the transition to socialism, which had been achieved during the first fiveyear plan. It was predicted that within a half-dozen years all litigation in the courts would cease; 55 some judges even closed their courts, and students passed resolutions questioning the necessity of continuing their studies. Such actions were all premised on the "bourgeois commodity-exchange" theory of law developed by Pashukanis. According to this theory ${ }^{56}$ all law was considered merely the reflection of the exchange of goods between private entrepreneurs. Since socialism had been achieved and private enterprise completely eliminated Pashukanis logically expected

I929, controlling jobs in open places during cold weather must be observed; transfers to other permanent or temporary work is controlled by the decree of the NKT of the USSR, Io April I930, etc. Dogadov, op. cit. supra note 2, at 87 .

sr Vsesoyuznyi Tsentral'nyi Sovet Professional'nykh Soyuzov.

${ }^{32}$ Decree of the TsIK [Central Executive Committee] of the USSR, SNK of the USSR and VTsSPS, 23 June 1933, SZ USSR [x933] No. 40, Art. 238.

s3 Decree of the SNK of the USSR and VTSSPS, to September 1933, SZ USSR [1933] No. 57 , Art. 333 .

54 Vsesoyuznyi Institut Yuridicheskikh Nauk, NKYu Soyuza SSR, Sovetskoe Trudovoe Pravo [All-Union Institute of Juridical Sciences, NKYu (People's Commissariat of Justice) of the Union of SSR, Soviet Labor Law] 6I (1939).

ss Schlesinger, Soviet Legal Theory 202 (I945).

${ }^{6}$ For a penetrating comment on Pashukanis, see Dobrin, Soviet Jurisprudence and Socialism, 52 L. Q. Rev. 402 (1936). Dobrin points out the influence of the German philosophers Laband and Jellinek on Pashukanis' commodity-exchange theory of law. 
that law would disappear in the Soviet Union. The national-economic plan would supplant law and only technical regulations under state planning would remain. As Pashukanis put it, "the plan is the law of the Soviet state."s7

But the theory was self-destructive when considered in the light of the official Soviet philosophy of dialectical materialism, ${ }^{58}$ as expounded by Marx and Engels and interpreted by Lenin and Stalin. The commodityexchange theory of law was considered as a "perversion" of Marxism and a dangerous attempt to undermine the authority of the Soviet state. According to the postulates of dialectical materialism, the state has always been throughout history, the dictatorship (instrumentality) of the ruling class, and law has always been the complex of norms (rules of conduct) which strengthen the dominant position of that class. ${ }^{59}$ Since the norms are created by the state, violators are subject to forms of state compulsion.

Lenin and Stalin established that a special type of state--the revolutionary dictatorship of the proletariat-functions during the transitional period from capitalism to communism. That is, the state continues to exist as the instrumentality of the ruling class-the proletariat. This transitional type of state is unlike those which have preceded it in history, according to Soviet theory, in that for the first time the state is not the instrumentality of a minority-exploiting class. The socialist state functions in the building of socialism, in the repression of the anti-social minority; and in mobilizing the resources of the nation for defense under conditions of "capitalistic encirclement." The state in the transitional period makes use of socialist law in effectuating its policies..$^{60}$

s7 Gintsburg and Pashukanis (ed.), Kurs Sovetskogo Khozyaistvennogo Prava, Kommunisticheskaya Akademiya, Institut Sovetskogo Stroitel'stva i Prava, Sektsiya Khozyaistvennogo Prava [Course in Soviet Economic Law, Communistic Academy, Institute of Soviet Construction and Law, Section for Economic Law] Vol. I, at 8 (I935): "Soviet economic law is the system of measures necessary for the solution of important organizational questions of the construction of the socialist economy. All its principles and institutions such as plandiscipline, one-man control [yedinonachalie], business-accountancy [khozraschet], contractdiscipline, etc., appear under close inspection as important means of organization of socialist industry and trade. The plan is the law of the Soviet state. Fulfillment of the plan is the holy obligation of each economic-organ, each industrial-manager and toiler."

$5^{8}$ Somerville, Soviet Philosophy, A Study of Theory and Practice (1946); Stalin, Dialectical and Historical Materialism, in Problems of Leninism 59I-6I8 (I940).

59 Osnovy Sovetskogo Gosudarstva i Prava I2 ( 1947 ).

${ }^{60}$ "As a means of control on the part of society, a means of regulating social relationships, a method and means of preserving the interests of socialist society and the rights and interests of citizens, Soviet law carries out a social function of gigantic importance-without which the socialist state could not get along until that time when it completely withers away." Vyshinskii (ed.), Sovetskoe Gosudarstvennoe Pravo [Soviet State Law] 55 (I938), translated by Babb sub. nom. The Law of the Soviet State (1948). For a complete discussion of the problems of law and state during the transitional period see ibid., c. I \& 3 . 
Therefore even before the promulgation in 1936 of the Stalin Constitution of "Victorious Socialism," the views of Pashukanis on the mutual exclusion of plan and law had been rejected. ${ }^{6 I}$ Under the leadership of Vyshinskii $^{62}$ traditional legal values were completely restored, and an amalgam of plan and law created. In developing a socialist law, the Soviet jurist has borrowed much from the jurisprudence of civil-law countries of the Continent, thus rejoining a tradition which goes back to the law of Rome.

\section{SOURCES OF SOVIET IAW}

\section{A discussion of the sources of law in general and its particular branches ${ }^{63}$} forms an important part of contemporary writing on Soviet law. Soviet theory, in common with all political theory, recognizes that the establish-

6x Vsesoyuznyi Institut Yuridicheskikh Nauk NKYu SSSR, Grazhdanskoe Pravo, Chast' Pervaya, Uchebnik Dlya Yuridicheskikh Vuzov [All-Union Institute of Juridical Sciences of the NKYu, Civil Law, First Part, Textbook for Juridical Schools] 36-43 (1938). (The chapter is entitled "Exposing the destructive 'theories' and criticism of anti-Marxist perversions in the literature of Soviet civil law.")

${ }_{2}$ "Pashukanis asserted: "The dying out of the categories of bourgeois law does not mean replacement of them with categories of proletarian law.' According to the destructive 'theory' of Pashukanis, once bourgeois law dies all law dies, without its re-establishment in any new form. Such a conclusion is not supported by any critique, let alone the viewpoint of dialectical materialism. It is absolutely incorrect to think that bourgeois law is the limit of the development of law, that in the future law is not bound to exist, that socialism and the proletariat have no need of law. What do Marx, Engels, Lenin, and Stalin say on this subject? They say directly the opposite. If socialism has no need of law, then why does socialism need the the state? Law is a form of policy, it is a form of activity of the state. If the state exists, then under certain historical conditions state policy may be expressed also in the form of law. Law is one of the means of regulation of social relations, of the strengthening of social discipline. The basic law of the Soviet state is the Constitution 'which is necessary in order to strengthen social forms favorable and suitable to the toilers.' (Stalin). In the Extraordinary VIII Congress of Soviets, comrade Stalin said: 'We must at last end the situation when not one organ legislates, but a whole series of organs. Such a situation conflicts with the principle of stability of laws. And stability of laws is necessary now more than ever before.' (Stalin, On the Draft of the Constitution of the USSR.)

"It is clear that under present historical conditions law and legislation are necessary, since they serve as the means of strengthening socialist victories. It is clear also that our law and our legislation may fulfill this role only as socialist law, as socialist legislation, and that the task of stability of Soviet law is the task of stability of Soviet socialist law. This excludes any ground for talking of the dying out of Soviet law, as did the 'school' of Pashukanis." Vyshinskii, K Polozheniyu na Fronte Pravovoi Teorii [The Situation on the Front of Legal Theory] 50 (1937). "Why is stability of laws essential? Because it reinforces the stability of the state order and of state discipline, and multiplies tenfold the powers of socialism mobilizing and directing them against forces hostile to socialism." Vyshinskii, op. cit. supra note 60, at 54 (Babb, at $5 \mathrm{I})$.

${ }_{63}$ "'On the basis of the difference in the social relations regulated, soviet socialist law is divided into the following branches: 1 ) state law, 2) administrative law, 3 ) financial law, 4) civil law, 5) labor law, 6) land law, 7) collective-farm law, 8) family law, 9) criminal law, ro) court law (divided into the judicial-system, criminal-procedural and civil-procedural law). A special place is occupied by international law, the norms of which are established chiefly by agreement of states with each other and which consequently does not enter directly into the system of law of individual states." Osnovy Sovetskogo Gosudarstva i Prava 83 (I947). 
ment of legal norms is one of the basic activities for the state. ${ }^{64}$ But according to Soviet theory, a given rule of conduct must be either created or sanctioned by the state to become a legal norm. Until the state acts, a rule of conduct is only an ethical norm. Continental and Soviet legal theory distinguish the various sources ${ }^{65}$ of the law according to the external forms by which they are established.$^{66}$ Legislation ${ }^{67}$ in the USSR is the sole source of law and other sources of law operate only as provided for by legislation. For example, Soviet legislation occasionally refers to custom $^{68}$ as a source of law. Only in the international field is agreement ${ }^{69}$ said to be a source of law. Judicial precedent is not generally recognized as a source of law, for according to Soviet and Continental theory, the court applies and does not create the law. ${ }^{692}$

The sole legislative organs in the USSR since 1936 are the Supreme

64"The most important form of activity of state power is the exercise of its highest power. This form of activity is expressed in the creation of general juridical norms (legislative activity) which regulate the most typical and stable relations, and in the resolution of the most important questions of state life. ... This form of activity is carried on by the highest organ of state power-the Supreme Soviet. . . . Some part of the plenary highest power is exercised by the Presidium of the Supreme Soviet, elected by the Supreme Soviet and responsible to it. Other forms of activity of the state have a character subordinate to the highest power. These are forms of exercise of subordinate power. Such forms are: $\mathbf{r}$ ) executive rule-making activity of the state (administration), 2) exercise of local power, 3) judicial activity of the state (justice)." Ibid., at 34.

65 For a discussion of the sources of Anglo-American law see Allen, Law in the Making (r946); Gray, Nature and Sources of the Law (2d ed., r93 I).

66 'By source of law in this special juridical sense is meant the form of establishment of norms of law, which is the basis of the binding force of the norm. A norm of law is binding as the command of the state, acting through a particular organ in a particular manner. This is the basis of the binding force of a legal norm. That form in which the state establishes the binding force of a particular rule of conduct, endowing it with this quality of a legal norm, is a source of law." Osnovy Sovetskogo Gosudarstva i Prava 43 (I947).

${ }_{67}$ "Legislation [zakon] is the general legal norm, deriving from the highest organ of state power, in a specially established manner. Soviet legislation is the direct expression of the will of the toilers. It is the basic source of law." Osnovy Sovetskogo Gosudarstva i Prava 44 (I947). Laws are divided into constitutional (fundamental) and ordinary in accordance with their significance. Constitutional laws establish the organization of state power and the basic principles of social and state structure. Ordinary laws may not conflict with constitutional laws and the latter are adopted or amended in a special manner (USSR Const. Art. I46). Ibid., at 46.

${ }^{68}$ Articles 89 and 90 of the Code of Commercial Navigation of the USSR suggest the use of the customs of a given port. Article 77 of the Land Code of the RSFSR authorizes the use of local custom for the definition of what property belongs to the members of a collective-farm household in the division of its property.

${ }^{69}$ This is not quite accurate. Although the collective agreement today does not operate as an important source of law those questions which still remain for the agreement of management and the factory committee of the trade union in the enterprise still are normative provisions. See text p. 467 infra.

${ }^{698}$ This is, of course, an oversimplification as regards Continental law. Gutteridge, Comparative Law c. VII (1946). For current reevaluations of this dogma by Soviet jurists see Hazard, The Soviet Court as a Source of Law, 24 Wash. L. Rev. 80, 90 (I949). 
Soviet of the USSR ${ }^{70}$ and the Supreme Soviets of the Union and Autonomous Republics. ${ }^{7 I}$ The constitutional power of the federal government to determine the bases of labor legislation limits the legislative power of the Union Republics to regulate labor. ${ }^{72}$ The federal power will soon be exercised more fully when the Supreme Soviet of the USSR adopts a federal code of basic laws on labor to which the various labor codes of the individual Union-Republics, ${ }^{73}$ if they continue to exist at all, will add only slight variations made necessary by the particular conditions existing in the Republic concerned.

Although the sole legislative organs in the USSR are the several Supreme Soviets, other organs may issue normative acts which are based upon legislation. ${ }^{74}$ These sources of law based on legislation are as follows:

I) Decrees of the Presidium of the Supreme Soviet of the USSR ${ }^{75}$ (and decrees of the Presidia of the Supreme Soviets of Union and Autonomous Republics ${ }^{76}$ )-Since the Presidium of the USSR functions between regular sessions of the Supreme Soviet, decrees of the Presidium may contain not merely norms based on legislation, but new norms. ${ }^{77}$ The Supreme Soviet of the USSR, however, must affirm such innovations at its next regular session. ${ }^{78}$

ro USSR Const. Art. 32. Compare Stalin's observation, note 62 supra, for the situation before 1936 .

${ }^{7 x}$ Articles 59 and $9 \mathrm{I}$ of the Constitution make the Supreme Soviets of Union-Republics and Autonomous Republics their sole legislative organs.

72 USSR Const. Art. 14 : "The jurisdiction of the Union of Soviet Socialist Republics, as represented by its higher organs of state power and organs of state administration embraces ... ( $t$ ) Determination of the principles of labor legislation."

${ }^{73}$ Hazard, Drafting New Soviet Codes of Law, 7 The American Slavic and East European Review 32 (I948).

74 Podzakonnye akty. "Organs of state power and state administration, which do not possess legislative power, in the course of their activity publish acts, which establish legal norms, i.e., obligatory rules of conduct the observance of which is guaranteed by state compulsion. In the Soviet state these norms are published on the basis of and in conformity with existing legislation and usually are elaborations of general norms, established by legislation. Acts based on legislation possess juridical force by virtue of legislation." Osnovy Sovetskogo Gosudarstva i Prava 47 (1947).

75 Article 48 of the Constitution of the USSR provides for the election of the Presidium of the Supreme Soviet of the USSR at a joint session of the two Chambers, and for accountability of the Presidium to the Supreme Soviet. Article 49 provides: "The Presidium of the Supreme Soviet of the USSR ... (b) Issues decrees [Ukazy]; c) Gives interpretations of the laws of the USSR in effect ... f) Annuls decrees and orders of the Council of Ministers of the USSR and of the Councils of Ministers of the Union-Republics if they do not conform to law. ..."

${ }^{76}$ Articles 61 and 93 of the Constitution of the USSR deal with the Presidia of the Supreme Soviets of Union and Autonomous Republics.

77 In establishing new norms, the Presidium exercises legislative power. See note 64 supra.

${ }^{78}$ For example, the important decree on absenteeism (progul) of the Presidium of the Supreme Soviet, 26 June r940, was affirmed by the Seventh Session of the Supreme Soviet of the USSR in August 1940. Aleksandrov, Sovetskoe Trudovoe Pravo 66 (1947). 
2) Decrees and orders of the Council of Ministers of the USSR ${ }^{79}$ (and decrees and orders of the Councils of Ministers of Union and Autonomous Republics)-The Council of Ministers ${ }^{80}$ in particular authorizes or affirms instructions and rules on existing labor legislation which are published by the VTsSPS. ${ }^{8 x}$ With the VKP (b) ${ }^{82}$ [All-Union Communist Party (of Bolsheviks)] the Council of Ministers of the USSR also promulgates important decrees regulating labor conditions. Joint enactments on wages, for example, are simultaneously normative acts of the Council of Ministers, and directives of the Communist Party.

3) Orders and instructions of the Ministers of the USSR ${ }^{8_{3}}$ (and orders and instructions of Ministers of Union-Republics ${ }^{84}$ )-Orders regarding safety technique and industrial sanitation may be issued by Ministers only with the approval of the central committee of the trade union concerned. ${ }^{85}$ A second and very important limitation on Ministers of the USSR and Councils of Ministers of Union Republics is that neither may publish orders affecting wages without the authorization of the Council of Ministers of the USSR. ${ }^{86}$

4) Judicial Precedent-While generally not a source of law in the Soviet Union, judicial precedent is so treated in one limited sense. Decisions of courts and settlements of the Appraisement and Disputes Commissions ${ }^{87}$ and other trade-union committees empowered to deal with

79 USSR Const. Art. 66: "The Council of Ministers of the USSR issues decrees and orders on the basis and in pursuance of the laws in effect, and verifies their execution." Before 1946 the Council of Ministers was called the Council of People's Commissars (Sovet Narodnykh Konzissarov, Soonarkom, SNK).

${ }^{80}$ Article 56 of the Constitution provides for the appointment of the Council of Ministers by the Supreme Soviet; Article 64 designates it as the "highest executive and administrative organ of state power." Compare Articles 79 and 93 for provisions relating to Union and Autonomous Republics.

8I Decree of the SNK of the USSR, 2I August 1934, SZ USSR [r934] No. 43, Art. 342.

${ }^{8 z}$ Vsesoyuznaya Kommunisticheskaya Partiya (bol'shevikov).

${ }_{3}$ USSR Const. Art. 73: "The Ministers of the USSR within the limits of the jurisdiction of their respective Ministries, issue orders and instructions on the basis and in pursuance of the laws in operation, and also of decrees and orders of the Council of Ministers of the USSR, and verify their execution."

${ }^{84}$ Article 85 of the Constitution of the USSR indicates the increasing complexity of restrictions as one proceeds down the heirarchy of the governmental structure: "Ministers of a Union-Republic, within the limits of the jurisdiction of their respective Ministries, issue orders and instructions on the basis and in pursuance of the laws of the USSR and of the Union Republic, of the decrees and orders of the Council of Ministers of the USSR and the Council of Ministers of the Union-Republic and of the orders and instructions of the Union-Republic Ministries of the USSR.

8s Decree of the SNR of the USSR and VTSSPS, ro September 1933, SZ USSR [I933] No. 57 , Art. 333 .

${ }^{86}$ Decree of the SNK of the USSR, 4 June r938, SP USSR [rys8] No. 27, Art. 179.

${ }^{87}$ See text p. 475 infra. 
labor disputes are not sources of law. But the guiding orders on questions of judicial practice, which the Plenum of the Supreme Court of the USSR issues in conformity with the Law on the Judicial System of $1938,{ }^{88}$ may be considered a source of Soviet law.

\section{NORMS OF SOVIET LABOR LAW}

The Soviet jurist divides labor law into norms of the General Part, which are common to the regulation of all types of labor relations and norms of the Special Part, which apply to specific labor relations. ${ }^{89}$ The Constitution of the USSR contains basic norms of the General Part. The Constitution designates work as "a duty and matter of honor for every able-bodied citizen." "90 It also covers the right of citizens of the USSR to work, "that is, the right to guaranteed employment and payment for their work in accordance with its quantity and quality." "9r

In its section on social structure the Constitution establishes the fundamental concepts of property. This section provides for the socialist system of economy and the socialist ownership of the instruments and means of production..$^{92}$ Socialist property is either state owned or is held by cooperatives and collective-farms. ${ }^{93}$ Norms of the Special Part reflect these concepts. Depending upon the kind of labor relations which are regulated the norms of the Special Part are divided into four groups. ${ }^{94}$ The first and most numerous group applies to workers (wage-earners) and employees (salary-earners) of state enterprises and agencies. ${ }^{95}$ A second group of

88 'For examination of protests lodged by the President of the Supreme Court of the USSR or the Procurator of the USSR against the verdicts, decisions and resolutions of the collegia of the Supreme Court of the USSR, a Plenum of the Supreme Court of the USSR is summoned, which likewise issues directions on questions of judicial practice founded on the decisions made by the Supreme Court of the USSR in cases examined previously." Article 75, Zakon o sudoustroistve SSSR, soynznykh, autonomnykh respublik [Law on the Judicial System of the USSR, union and autonomous republics] I $_{7}$ Sovetskaya, Yustitsii [Soviet Justice] 4 (I938) (translated in 17 The Slavonic Rev. 452 [r939]).

${ }^{89}$ Aleksandrov, Sovetskoe Trudovoe Pravo 67 et seq. (I947).

90 USSR Const. Art. I2.

92 USSR Const. Art. 4.

$9 x$ USSR Const. Art. 118.

93 USSR Const. Art. 5 .

94 Aleksandrov, Sovetskoe Trudovoe Pravo 68 (1947).

95 Rabochii, translated as worker (wage-earner), has the connotation of manual worker; sluzhashchii, translated as employee (salary-eamer), has the connotation of "white-collar worker." Predpriyatiye has been translated as enterprise. "The basic production unit, the 'plant' or 'enterprise,' is never easily defined. Precision is naturally difficult in the case of the USSR, where the nationalization of all important economic activities has done away with many old legal concepts without creating exact substitutes. In the terminology of Russian official statistics, an independent industrial plant (predpriyatiye, literally, enterprise) has its own balance sheet and plan of production and finance; some fixed capital (machines, building) and working capital; and an independent current account at the State Bank." Bienstock, Schwarz and Yugov, Management in Russian Industry and Agriculture 8 (rg44). 
norms of the Special Part regulates labor relations in collective-farms. ${ }^{96}$ The relations of craftsmen with the craft artel are covered by a third group..$^{97}$ Finally, in conformity with the KZoT of the RSFSR, ${ }^{98}$ a fourth group of norms determines the labor conditions of persons engaged in compulsory labor service. This service involves work of a temporary nature in connection with natural disasters or road construction if a labor shortage exists in a particular area. All citizens, whether workers, employees, members of collective farms or craft artels are subject to call on the basis of decrees of the Council of Ministers of the USSR, but citizens taken for compulsory labor service keep their permanent jobs.

Compulsory labor service should be distinguished from the general labor mobilization which took place during World War II. ${ }^{99}$ Able-bodied city dwellers were mobilized in the areas where they lived for work in the aviation, munition, metallurgy, chemical, fuel, and tank production indus-

${ }_{96}$ The basic normative act which regulates collective-farm labor relations in particular is the Model Charter of the Agricultural Artel, adopted by the Second All-Union Congress of Collective-farm Shock-workers (kolkhozniki-udarniki), and affirmed by the SNK of the USSR and Central Committee of the VKP(b) on 77 February I935. A Decree of the Council of Ministers of the USSR and Central Committee of the VKP(b), I9 September 1946, deals with remedying violations of the Charter. SP USSR [1946] No. 13, Art. 254.

97 The basic normative act which regulates the membership in a craft artel, including the labor relations of members with the artel as a whole, is the All-Union Regulation on Craft Cooperatives, affirmed by a decree of the TsIK and the SNK of the USSR, II May, 1927, SZ USSR [1927] No. 26, Art. 280. In the RSFSR, artels are regulated by the Regulation on Craft Cooperatives, affirmed by the VTsIK (The All-Russian Central Executive Committee) and the SNK of the RSFSR, II June I928, SU RSFSR [x928] No. 86, Art. 567. SU RSFSR is the abbreviation of Sobranie Uzakonenii i rasporyazhenii Raboche-krest'yanskogo pravitel'stva RSFSR [Collection of ordinances and orders of the Worker-peasant government of the RSFSR].

${ }^{98}$ Article II of the KZoT RSFSR provides for compulsory labor service in exceptional cases (fighting the elements, lack of workers to carry out important state tasks) based on special decrees of the SNK. Article 12 makes exceptions for persons under I8, men over 45, and women over 40 . Article $I_{3}$ covers other forms of exemption (pregnant women, persons temporarily incapacitated because of illness, etc.). This is the remnant of the general duty to work of the KZoT RSFSR of 1918. The labor relations of persons called upon for compulsory labor service are regulated by the Decree of the VTsIK and SNK of the RSFSR, 18 July I927, SU RSFSR [1927] No. 73, Art. 500. The exceptions mentioned in Articles I2 and I3 of the KZoT RSFSR were narrowed during World War II. Only persons under 16 , men over 55 , and women over 45 were exempted.

99 By Decree of the Presidium of the Supreme Soviet of the USSR, 26 June I94I, obligatory overtime work at the authorization of the SNK from one to three hours a day was introduced, and ordinary and supplementary vacations during wartime were replaced by money compensation. The Decree of the Presidium of the Supreme Soviet of the USSR, I 3 February 1942, covered the mobilization of the able-bodied remainder of city population not working in state enterprises and agencies as workers and employees in industry and construction. The power indicated in Article $x I$ of the KZOT RSFSR was exercised by SNK USSR on ro August 1942 by a decree authorizing compulsory labor service (in addition to cases of fighting fires, epidemics, and natural disasters), to fill worker quotas in defense projects and special building tasks up to a period of two months. Aleksandrov, Sovetskoe Trudovoe Pravo 62 et seq. (I947). 
tries. Those in city and rural areas who were mobilized for permanent work in industry and construction in places other than where they lived received additional compensation. Both compulsory labor service and general wartime labor mobilization must be distinguished from corrective-labor ${ }^{\text {I0o }}$ which is a form of punishment provided by the criminal codes of Union-Republics.

\section{NORMS REGULATING WORKERS AND EMPLOYEES}

The conclusion of a contract of employment ${ }^{\mathrm{zox}}$ in Soviet law establishes a legal relation ${ }^{\mathrm{x} 2}$ between the worker and the management of the enterprise. When citizen Ivanov concludes an employment contract with the Stalingrad Tractor Works, the agreement of the parties determines that he will work at this plant and that he will work, say as an accountant. But the content of the legal relation which is thus established is determined today by the hierarchy of sources of Soviet labor law.

I. Union of Soviet Socialist Republics.-Since a proposed draft of a federal (All-Union) code of basic laws on labor (KZoT) has not yet been adopted by the Supreme Soviet of the USSR, federal legislation, and enactments of the Council of Ministers of the USSR, exist only as separate pieces of legislation or decrees. The KZoT of the RSFSR and other individual Union Republics in official supplements ${ }^{\mathrm{T03}}$ contain important federal materials on labor.

2. Union-Republics.-The KZoT of each Republic is the basic legisla-

${ }_{200}$ Ugolovnoe Kodeks [Criminal Code] RSFSR Art. 20. See also the Ispravitel'no Trudovoi Kodeks. [Corrective-Labor Code] RSFSR, SU RSFSR [I924] No. 86, Art. 870 (translated in Accounts and Papers, Twenty Volumes, op cit. supra note $I X)$.

ror KZoT RSFSR Art. 27: "An employment contract shall mean an agreement between two or more persons whereby one party (the employee) places his labor at the disposal of the other party (the employer) in return for remuneration. A contract of employment may be concluded whether a collective agreement exists or not." Workers and employees, upon beginning work, must submit their labor booklet to the management of the enterprise or agency. Decree of the SNK of USSR, 20 December x938, SP USSR [1938] No. 58, Art. 329.

${ }^{102}$ "Social relations, insofar as they are regulated by legal norms, acquire the form of legal relations (juridical relations). The outstanding characteristic of a legal relation is that one party may demand specific conduct from another, with possible protection of such a claim by judicial or administrative organs. ... [A] labor legal relation may be defined as that juridical relation in which one party (the worker) must perform work, having entered into the working force of an enterprise (agency, business) and having become subject to the rules of employment of the enterprise; and the other party (a juridical person, or physical person as the owner of a business satisfying personal needs) is obligated to pay compensation for the work and to guarantee labor conditions which are conducive to health and contribute to the productivity of labor." Aleksandrov, Sovetskoe Trudovoe Pravo 8I-82 (1947).

${ }^{03}$ The KZoT RSFSR contains federal legislation in its supplement, covering such subjects as labor conditions in seasonal jobs, labor conditions of temporary workers and employees, compensation and guarantees in transfer to other places of work, pensions and aids from social insurance, rates of payment of social insurance, etc. 
tion on labor in the sixteen Union-Republics. The present KZoT of the RSFSR, ${ }^{\text {x04 }}$ promulgated during the NEP in I $^{222}$, has been changed in a majority of particulars by subsequent federal and Union-Republic legislation. The federal law prevails ${ }^{\mathrm{ros}}$ when it is in conflict with Union Republic legislation.

3. Rules of the VTSSPS.-Instructions, rules, and explanations concerning application of labor legislation affecting workers and employees have been published by the VTSSPS with the authorization or affirmation of the Council of Ministers of the USSR ${ }^{106}$ since the liquidation of the NKT in I933. Rules on safety technique and industrial sanitation are established by the central committees of the trade unions with the approval of the proper departments of Ministries. All instructions and rules formerly issued by the NKT which are not inconsistent with later legislation are still in force.

4. Rules of employment. ${ }^{107}$-The Soviet Constitution ${ }^{\text {xo8 }}$ provides that each citizen must observe labor discipline. Rules of employment for a given enterprise stipulate the general and specific obligations of workers and the management, and define the sanctions imposed for violations. The basic content for rules of employment is determined by the Model rules of employment for workers and employees of state, cooperative and public enterprises and agencies, of $\mathrm{I} 94 \mathrm{I} .{ }^{\mathrm{X}}{ }^{09}$ On the basis of the Model rules, branch rules

so4 The KZoT RSFSR in 1947 was effective in all Union-Republics created out of the RSFSR. By Decree of the Presidium of the Supreme Soviet of the USSR, 6 November I940, the KZOT RSFSR has been temporarily extended to the territories of the Latvian, Lithuanian, and Estonian Union-Republics.

105 USSR Const. Art. 20.

${ }^{106}$ Decree of the SNK of the USSR, 2I August 1934, SZ USSR [1934] No. 43, Art. 342.

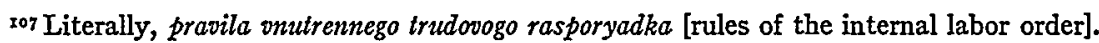

${ }^{108}$ USSR Const. Art. $\mathrm{x}_{30}$ : "It is the duty of every citizen of the USSR to abide by the Constitution of the Union of Soviet Socialist Republics, to observe the laws, to maintain labor discipline, honestly to perform public duties and to respect the rules of socialist mores."

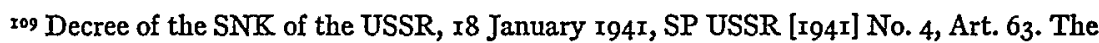
Model Rules of Employment consist of five sections: I) general considerations; 2) method of hiring and dismissal of workers and employees; 3 ) basic obligations of the management, workers, and employees; 4) working time and its use; 5) fines. Article I states: "In the Soviet Union, labor discipline is based on a conscientious attitude towards work as a matter of honor, glory, valor, and heroism." Article 2 considers the purpose of rules of employment as guaranteeing the "strengthening of the socialist discipline of labor, the correct organization of work, the full and rational use of working time, the increased productivity of labor, and the output of goods of high quality." Articles 9 and ro contain typical obligations of management and workers. Violations of labor discipline may be punished by the imposition of a disciplinary fine, or by criminal prosecution. If a worker as the result of a violation of labor discipline has damaged the enterprise, for example spoiled a lathe because of carelessness, then in addition to a disciplinary fine or criminal responsibility he may have to make good the damage (material responsibility). Golyakov, Zakonodatel'stvo o Trude 49-6r (I947). 
of employment which conform to the needs of a particular industry are published by Ministries of the USSR and Union-Republics with the approval of the central committees of the appropriate trade unions. In cases of necessity the director of an enterprise or agency with the approval of the factory or local committee may supplement the rules of employment.

\section{The Soviet Collective Agreement and the Postwar Five-Year Planiso}

The period of Soviet reconversion at the end of World War II saw the repeal of special wartime labor legislation. ${ }^{\text {Irx }}$ In I945, decrees of the Presidium of the Supreme Soviet of the USSR provided for the cessation of compulsory overtime work, re-establishment of vacations for workers and employees who had been compelled to accept money compensation in their stead, and revocation of wartime legislation on the mobilization of labor reserves.

With promulgation by the Supreme Soviet of the USSR, the law establishing the fourth five-year plan (1946-50) became effective on March I8, I946. This law maintains the eight-hour working day which was introduced in I940 (after a period in which the seven-hour day was in effect) and emphasizes increasing the productivity of labor through the application of incentive systems such as piecework and premium payments. According to the plan the wage fund is to grow from $\mathrm{x} 62$ billion rubles for I940 to $25^{2}$ billion rubles in I950. The law also obligates ${ }^{\mathrm{Tr2}}$ the Council of Ministers of the USSR to guarantee the "universal attraction of workers, peasants and the intelligentsia to the task of fulfilling the five year plan on the basis of socialist emulation. ..." ${ }^{\mathrm{Ir} 3}$ This device, and the Stakhanov

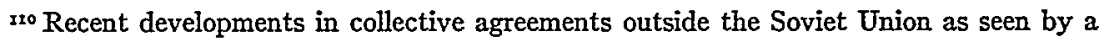
Soviet jurist are reported in Pasherstnik, Kollektivnyi Dogovor v Burzhuaznykh Yuridicheskikh Teoriyakh i Zakonodatel'stve Kapitalisticheskikh Stran [The Collective Agreement in Bourgeois Juridical Theories and Legislation of Capitalistic Countries] x Izvestiya Akademii Nauk SSSR, Otdelenie Ekonomiki i Prava [News of the Academy of Sciences of the USSR, Section for Economics and Law] 39 (x948).

Ixx Aleksandrov, Sovetskoe Trudovoe Pravo 62-63 (r947). $\quad{ }_{1 x 2}$ Ibid., at 64 .

${ }^{\times 3}$ Sotsialisticheskoe sorevnovanie, literally, "socialist competition" has been translated "socialist emulation." It is a method of increasing the productivity of workers by arranging competitions between departments, shops, and enterprises. See Baykov, op. cit. supra note 3, at 220 et seq.; Bienstock et al., op. cit. supra note 95, at 9r et seq., for a discussion of Soviet incentives. New collective agreements must be directed towards the achievement "of such tempos of increase in production, which will allow the fulfilment of the five-year plan in four years." In conformity with this task the plenum of the VTsSPS recommended to factory committees and local committees "the acceptance in collective agreements of obligations for the further development of All-Union socialist emulation of workers, engineering and technical personnel, and employees and for the organization of collective Stakhanov work in brigades, in sections, and in shops; to widely support the socialist emulation of workers, undertaking personal obligations for the premature fulfilment of the year plans and the five year plan as a whole. ..." Pasherstnik, op. cit. supra note 28 , at 39 . 
movement" ${ }^{\mathrm{x} x}$ represent forms of the "socialist organization" of labor.

To aid in the task of "fulfilling the five-year plan in four years" in I947 collective agreements were ordered to be concluded in enterprises of industry, transportation, and construction. A suggestion of the VTsSPS, approved by a decree of the Council of Ministers of the USSR, February 4, I947, initiated the conclusion of twenty-five thousand collective agreements covering fourteen million workers.

Disregarding the historical record, ${ }^{\text {Irs }}$ some Soviet textwriters and commentators still attempt to describe contemporary collective agreements and rules of employment as important sources of law, belonging to the class of "normative agreements." ${ }^{\text {II6 }}$ Even as early as the first five-year plan the nature of the collective agreement had begun to change. Descriptions of the collective agreement as only the unilateral obligation of the management of the enterprise were rejected even then as "bourgeois" and "counter-revolutionary." Today the collective agreement is described as ... an agreement concluded between the enterprise in the person of the management, and the collective body of workers and employees in the person of the factory-committee, which establishes mutual obligations of the enterprise, workers and the trade union organization for the fulfillment and overfulfillment of the state production plan

${ }^{1 x 4}$ The Stakhanov movement (named for Aleksei Stakhanov, a miner who by a rationalization of the mining process in which he was engaged achieved an extraordinarily high level of productivity) was established in 1935 during the second five-year plan, and has now been introduced into all branches of the economy. Stakhanovites intensify their efforts, and apply inventions and rationalizations to their work to achieve higher productivity. "Stakhanov schools" consisting of a Stakhanovite and four or five young workers have been set up in enterprises. Stakhanovites receive, in addition to higher wages, substantial other privileges. See Bienstock et al., op. cit. supra note 95 , at 44 et passim.

xrs Pasherstnik, op. cit. supra note 28, and Dogadov, op. cit. supra note 2; attack this failure to recognize the elimination of the collective agreement as a source of law. Also Shvernik, Zadachi profsoyuzov v soete reshenii XVIII s'ezda VKP(b) [Tasks of trade unions in light of the resolution of the XVIII congress of the $V K P(b)] 4$ Profsoyuzy SSSR [Trade Unions of the USSR] 5 (1940).

${ }_{126}$ "The collective agreement, therefore, belongs to the class of so-called normative agreements, i.e., agreements on the establishment of general rules (or norms), which regulate a certain complex of personally indefinite relations." Aleksandrov, Sovetskoe Trudovoe Pravo 73 (1947). The view that the Soviet collective agreement is today an important source of labor law is also presented by Moskalenko, Pravovye voprosy kollektionogo Dogovora [Legal Questions Concerning the Collective Agreement] 8 Profsoyuzy SSSR I8 (I948). Examples of normative agreements which operate prominently in the Soviet legal system today are the various Basic Conditions of Supply concluded between supplier-ministries and consumer-ministries concerning planned goods. The Basic Conditions of Supply regulate the contents (prices, quantities) of direct contracts of supply concluded by individual enterprises within the systems headed by the ministries involved. Disputes between ministries in the formulation of Basic Conditions of Supply are heard by tribunals of the State Arbitration Commission as the so-called precontractual disputes. Agarkov and Genkin (eds.), Grazhdanskoe Pravo, Vsesoyuzni Institut Yuridicheskikh Nauk NKYu SSSR, Institut Prava Akademii Nauk SSSR [Civil Law, AllUnion Institute of Juridical Sciences of the NKYu, of the USSR, Institute of Law of the Academy of Sciences of the USSR] Vol. II, at 25 (rg44). 
authorized for the enterprise, and for the securing of appropriate material and cultural living conditions and other labor conditions of workers and employees. ${ }^{117}$

This definition is in strict conformity with the purposes of collective agreements concluded for r 947 , as defined by the Council of Ministers of the USSR. ${ }^{18}$ The definition today contrasts sharply with the formulation of the KZoT of the RSFSR where emphasis was put on the legal nature of the collective agreement as a source of law.

\section{PREPARATION AND REGISTRATION}

In Soviet law the enterprise has the civil-law capacities of a juridical person. ${ }^{119}$ Territorial organs of the trade union are also considered juridical persons, but the factory committees, the lower units of the trade-union system, are not. ${ }^{\mathrm{x} 20}$ It seems clear that the management of the enterprise is the agent of one party to the collective agreement-the enterprise, and the factory committee is the agent for the other party-the collective body of workers and employees in the enterprise. The organization of socialist emulation among the workers is primarily the responsibility of the factory committee ${ }^{\mathrm{Iar}}$ but the personnel of both management and the factory committee also undertake personal obligations.

The management and factory committee draft the collective agreement in a climate of intensive political and organizational activity ${ }^{122}$ As many workers and employees as possible are drawn into the process. The provisions are discussed on the radio, in meetings, at lectures, and in publications. In those enterprises in which collective agreements were concluded, ninety-five per cent of all workers are reported to have participated in meetings devoted to the discussion of collective agreements for $1947 . \mathrm{Nu}-$ merous suggestions of workers dealing with invention and rationalization of industrial processes were either embodied in the collective agreement

xx7 Pasherstnik, op. cit. supra note 28 , at 50 .

${ }^{128}$ Golyakov, Zakonodatel'stvo o Trude 5 (1947).

xx9 See Bratus' Yuridicheskie Litsa v Sovetskom Grazhdanskom Prave, Vsesoyuznyi Institut Yuridicheskikh Nauk Ministerstva Yustitsii SSSR [Juridical Persons in Soviet Civil Law, All-Union Institute of Juridical Sciences of the Ministry of Justice of the USSR] 2I2 et seq. (1947); Venediktov, Gosudarstvennaya Sotsialisticheskaya Sobstvennost'; Akademiya Nauk SSR, Institut Prava [State Socialist Property, Academy of Sciences of the USSR, Institute of Law] 7 I2 et seq. (I948). See Hazard, Soviet Government Corporations, 4r Mich. L. Rev. 850 (r943).

${ }^{220}$ Circular of the VTsSPS of I8 January I927; Golyakov, Zakonodatel'stvo o Trude 236 (1947).

22x See note II3 supra.

I2 Sidorenko, O Zakluchenii Kollektivnykh Dogovorov na Prepriaitiaikh Promyshlennosti Transporta i Stroitel'stva na I947 god. [On the Conclusion of Collective Agreements in Enterprises of Industry, Transport and Construction for the year 1947] 40 (x947). 
or immediately put into operation. Workers become acquainted with production problems and assume personal obligations to participate in "socialist emulation" during the discussion and drafting of collective agreements.

Within the context of the promfinplan and the funds allotted for the enterprise, the collective agreement is the end-product of a planning process which begins with the establishment of quotas in the national-economic plan devised by Gosplan. The VTsSPS together with the appropriate Ministries authorizes model collective agreements for individual branches of the economy. ${ }^{123}$ The manner of concluding collective agreements is governed by directives embodying the indices fixed for enterprises by the state plan; these directives are issued by Ministries and central committees of trade unions with the approval of the VTsSPS. ${ }^{x 24}$

Today collective agreements are subject to registration in the appropriate ministry and central-committee of the trade union. ${ }^{x 25}$ Ministries and the VTsSPS exclude from collective agreements systems of payments which have not been authorized by the Council of Ministers of the USSR. In contrast to the KZoT of the RSFSR, today any labor conditions which are merely inconsistent with the indices of the plan are revised upon registration. When an enterprise is transferred from one department to another so that its production program is changed, however, collectiv ${ }^{\circ}$ agreements are still subject to revision.

During the life of the collective agreement, factory committees ${ }^{126}$ make

${ }_{223}$ Article 2 of the Decree of the Council of Ministers, 4 February I947. Golyakov, Zakonodatel'stvo o Trude 326 (1947).

224 "Such directives must cover: $I$ ) indices authorized for enterprises by the state plan on the output of products in absolute terms or percentages relating to the indices for the previous year, on the productivity of labor, payments, cost of products, grants for housing and cultural construction and the protection of labor; 2 ) indices on the preparation of new cadres and on raising the qualification of workers and employees; 3 ) indices authorized for enterprises on auxiliary economy, including the raising of live-stock and birds; 4 ) indices on individual housing construction, and also the amounts and forms of aid for individual construction (in branches of industry where enterprises are subordinate to trusts, the indicated indices are given for trusts and the latter establish them for enterprises); 5) orders to factory committees of trade unions on the development of socialist emulation, on aiding workers, engineering and technical personnel and employees to increase their production qualifications, on the control of the observance of labor legislation and the correct carrying out of the authorized system of payments, on measures for strengthening of labor discipline of workers and the struggle with stoppage and spoilage." Article 4 of the Decree of the Council of Ministers of the USSR, 4 February 1947. Ibid.

${ }^{225}$ Article 7 of the Decree of the Council of Ministers of the USSR, 4 February 1947. Ibid., at $325-26$.

${ }^{226}$ The factory committee is subdivided into various commissions. The most important of these is the wage commission, the duties of which are broader than its name implies. Among other things it aids the factory committee in the organization of socialist emulation. Other commissions in the factory committee are the commission on the protection of labor, council on 
periodic reports to the workers which reveal how all parties to the agreement are carrying out their obligations. Cases of ignoring the collective agreement by management or the factory committee have not been rare. Therefore the Council of Ministers of the USSR in its decree of February 4, I947 required trade-union and economic organizations to assume greater responsibility for the living conditions of workers of the enterprise.

\section{THE SOVIET SYSTEM OF WAGES AND SALARIES}

Collective agreements in countries outside the USSR deal primarily with wages. Wage provisions in Soviet collective agreements are not the product of bargaining at the enterprise level but merely references to the state system of wage regulation. Collective agreements today fix wages only in concessionaire enterprises. In employment contracts for special types of work the agreement of the parties also determines the amount of wages. ${ }^{\text {I27 }}$

Wage rates in the Soviet Union are based on either time or piecework. ${ }^{128}$ In both cases premium payments are made for achievement of specified levels of work. The elements of the governmental wage system are: I) wage scales, ${ }^{\text {r29 }}$ 2) wage rates, 3 ) qualification handbooks. The wage scale

social insurance, housing commission, commission on cultural work, commission on invention and rationalization, commission on supply of workers, commission on work among children, commission on gardening and livestock raising, and local council of the trade-union physical culture society. Golyakov, Zakonodatel' stvo o Trude 238 (I947).

${ }^{127}$ This is true in the employment of domestic workers, and in several other cases covered by legislation on labor. In the employment of workers in the arts, press, and education, the amount and method of payment is established by agreement of the parties. Decree of the NKT of the USSR, II November rg29. Aleksandrov, Sovetskoe Trudovoe Pravo I77 (r947).

${ }^{228} \mathrm{KZoT}$ RSFSR Art. 60.

${ }^{2 a 9}$ As an example, the following is the wage scale for repair workers in the Novo-Tul'skii metallurgy plant:

\begin{tabular}{|c|c|c|c|c|c|c|c|c|}
\hline & \multicolumn{8}{|c|}{ Categories } \\
\hline & $\mathbf{r}$ & 2 & 3 & 4 & 5 & 6 & 7 & 8 \\
\hline \multirow[t]{2}{*}{ Coefficients..... } & $1 . \infty$ & 1.20 & $\mathrm{x} .45$ & I.70 & 2.10 & 2.50 & $3 . \infty$ & 3.60 \\
\hline & \multicolumn{8}{|c|}{ Hourly Wage Rates of Piece-Workers (in Rubles and Kopecks) } \\
\hline \multirow[t]{2}{*}{$\begin{array}{c}\text { For work under } \\
\text { normal condi- } \\
\text { tions.......... }\end{array}$} & $75 \mathrm{k}$. & 9ok. & Ir.ogk. & Ir. 27k. & Ir. $57 \mathrm{k}$. & Ir.87k. & $25.25 k$. & 2r. 7 ok. \\
\hline & \multicolumn{8}{|c|}{ Hourly Wage Rates of Time-Workers } \\
\hline $\begin{array}{c}\text { For work under } \\
\text { normal condi- } \\
\text { tions........... }\end{array}$ & $66 \mathrm{k}$. & $79 \mathrm{k}$. & $96 \mathrm{k}$. & rr. I2k. & Ir. $39 \mathrm{k}$. & Ir. $65 \mathrm{k}$. & Ir. $98 \mathrm{k}$. & $2 \pi .38 \mathrm{k}$. \\
\hline
\end{tabular}

Source: Golyakov, Zakonodatel'stvo o Trude 69 (I947). 
consists of different categories based on the wage rate for the most unskilled form of work in a particular industry. The wage rate for each category is determined by multiplying the basic wage rate by the coefficient for that category. Since piecework payments involve greater productivity and effort, the wage rate is somewhat higher. Wage scales and rates vary with the nature of the industry.

Wage qualification handbooks contain descriptions of all types of trades and jobs in a given branch of industry with the wage category which has been assigned to the job. On the basis of the wage qualification handbook each worker is assigned an appropriate category.

Industrial workers are generally paid on the basis of piecework. Payments for piecework are fixed on the basis of standards of output and appraisals for each unit produced. Soviet industry favors piecework payments because earnings directly depend on output; and it is said they stimulate productivity and at the same time increase the earnings of workers. Since time payments do not have this effect, Soviet policy does not approve of this method of payment for industrial workers. Time payments are utilized only in those industrial jobs for which the establishment of a standard of output is impossible.

Piecework appraisements are made on the basis of standards of output fixed by the government. A standard of output is either the number of items or operations which the worker under normal conditions must complete within a fixed period of time (hour or day), or the interval of time (minutes or hours) during which an item or operation should be completed by a worker under normal conditions. If the standard is expressed in the number of items, appraisement for each item is made by dividing the wage rate by the standard of output. For example, if the hourly wage rate for a particular category is ten rubles and the standard of output is twenty items or operations, then appraisement for one item or operation is equal to ten rubles divided by twenty, or fifty kopecks.

If the standard is expressed in intervals of time, appraisement is made by multiplying the wage rate by the standard of output. For example, if the hourly wage rate of the category is ten rubles and one item or operation must be completed in two hours, appraisement for one item or operation is ten times two, or twenty rubles.

Employees of enterprises and agencies, and the managerial staffs of enterprises usually receive bi-monthly salaries which are fixed by normative acts of the State Staff Commission in the Council of Ministers of the USSR. ${ }^{3^{\circ}}$ Evaluation of the qualifications demanded, responsibility at-

${ }^{230}$ Decree of the SNK of the USSR, 5 June I94I. This decree introduced limitations on Ministers and Councils of Ministers of Union-Republics regarding reorganization of manage- 
tached to the job, and the location where the work is to be performed influence the salary determination. Medical employees, for example, receive higher salaries in outlying areas than in metropolitan districts.

Personal salaries may be paid to individuals who have special experience in the work assigned to them, and who have been designated by certain All-Union Ministers of the USSR and Councils of Ministers of UnionRepublics. ${ }^{\text {I3 }}$

\section{LEGAL AND NONLEGAI ASPECTS OF COLLECTIVE AGREEMENT OBLIGATIONS}

Collective agreements contain obligations created solely by the parties and obligations which arise from labor legislation ${ }^{132}$ or are imposed by the national-economic plan. ${ }^{\mathrm{x} 3} \mathrm{In}$ fact, the relationship between the two types of obligations has caused confusion in Soviet law. Different governmental organs in 1947 issued conflicting orders as to the necessity of incorporating in collective agreements labor conditions already fixed by legislation. ${ }^{\mathrm{T} 34}$ As a matter of practice collective agreements did include a number of labor conditions which had already been defined in legislation. It has been suggested that obligations which derive from legislation be repeated in collective agreements only if such legislation has an educational value ${ }^{x 35}$

ment personnel. Karinskii, Pravovoe regulirovanie zarabotnoi platy rabochikh, sluzhashchikh promyshlennykh predpriyatii [Legal regulation of wages of workers and employees of industrial enterprises] 22 (I943). (I947).

${ }^{{ }_{33}}$ Decree of the SNK of the USSR, 5 April 1945. Golyakov, Zakonodatel'stvo o Trude 72

${ }^{{ }_{32} 2}$ Grazhadanskii Kodeks [Civil Code] (hereafter, GK) RSFSR Art. I06: "Obligations may arise out of agreement (contract) or are based on other grounds indicated in legislation, in particular, unjust enrichment or causing injury to another person."

${ }_{333}$ Pasherstnik lists the sources of obligations in the collective agreement as follows (the importance of the various sources may be ascertained from his examples): I) obligations the content of which is defined by the state plan (gross output of products, productivity of labor); 2) obligations the content of which is defined by legislation on labor (payment of labor, vacations, etc.); 3) obligations the content of which is defined by agreement of the parties to the collective agreement (manner of payment for performance of work rated lower than the category assigned to the worker, notifying workers of standards of output three days before they go into effect). Pasherstnik, op. cit. supra note 28, at 52.

${ }_{34}$ As a general rule directives of ministries and central committees of trade unions indicated that it was not necessary to repeat in collective agreements what was covered by legislation. For example, the directive of the Minister of the Transport Machinery Industry and the central committee of the union workers in that industry indicated that "... in collective agreements there must not be included labor conditions covered by legislation. ..." Ibid. At the same time a Decree of the Presidium of the VTsSPS provided, "Collective agreements should indicate the scales authorized by the government for piecework, piecework-progressive and premium payments." Tbid.

${ }_{135}$ "The collective agreement today usually includes norms regulating payment (wage scales with coefficients and rates, scales of progressive payments, etc.). But these norms are not the result of collective agreements. They derive from the appropriate organs of state power. 
for workers and employees or if the obligations contained in legislation are pertinent to a particular enterprise.

Obligations created by agreement of the parties ${ }^{\mathrm{x} 36}$ are either legal or ethical in character. Criminal, administrative, or civil law sanctions may be imposed solely for violation of legal obligations. The obligations of the enterprise and the obligations of the management when acting for the enterprise are legal in nature. The enterprise may be compelled to fulfill any of its contractual obligations in the agreement. ${ }^{\mathrm{x} 37}$ The function of

Inclusion of such norms in the collective agreement has the purpose of acquainting the collective body of workers in the enterprise with them, and of mobilizing workers and employees in the struggle for the plan." Dogadov, op. cit. supra note 2, at 92.

${ }^{236}$ Typical obligations of the parties taken from the Model Collective Agreement for Enterprises of the Ministry of the Transport Machinery Industry for $\mathrm{r} 947$ follow.

I) Joint obligations: the obligation of management, factory-committee, employees, workers, engineering and technical personnel: ". . . to guarantee the unconditional fulfillment and overfulfillment of the state plan established by the government on the basis of the development of socialist emulation, the most rapid assimilation of new technique, increase in technical knowledge and production skills, establishment of firm discipline of labor, elimination of defects in the organization of labor and industry, observance of the strictest economy in the expenditure of materials and financial resources and a decisive struggle with spoilage and spoilers."

2) Obligations of the enterprise: "... to take the necessary steps to guarantee the fulfillment and overfulfillment by workers of the established standards of output, the organization of technical instruction, timely and adequate repair of equipment and machine-tools, technical assistance to rationalizers and inventors, organization of the rapid introduction of suggestions accepted for rationalization and invention ... payment of workers and employees according to the established standards and over the fixed periods of time, carrying out the construction and repair of housing."

3) Obligations of workers and employees: ". . . to best use the working day, to work without spoilage, conscientiously and in the time allotted for the fulfillment of production tasks, to carefully treat the equipment, instruments, materials and other plant property as sacred socialist property."

4) Obligations of the factory-committee: ". . to systematically check the conformity of the system of payments applied to the ones authorized ... to exercise control over the observance of existing legislation on labor discipline and rules of employment authorized by the management ... to carry on en masse explanatory and educational work concerning the complete introduction of the socialist discipline of labor ... to offer workers and employees a certain number of permits for rest-homes and sanitaria." Pasherstnik, op. cit. supra note 28, at 50-5I.

Even more interesting are examples of very specific obligations, such as those listed in the draft of the collective agreement worked out for the Artillery Plant I. V. Stalin of the Ministry of Munitions of the USSR, viz., to construct a school for workers' children with a capacity for 600 students; to build a clinic for workers in the plant; to construct and put in to operation one five-floor apartment-house, three two-floor apartment-houses and three three-floor apartment-houses with an overall space of 6,000 square meters. Dogadov, op. cit. supra note 2, at 89. See also the obligations of the management in the allotment of $1,260,000$ rubles for the building of dwellings in the Collective Agreement of the Fraising-Lathe Workers at Gorki for the Year 1933-34, translated in S. and B. Webb, Soviet Communism: A New Civilization? Vol. I, at 520-2I (I935).

${ }^{237}$ Even though the enterprise assumes an obligation to furnish housing to workers, a claim may not be immediately asserted on the basis of the collective agreement. If priorities are given to certain classes (e.g., workers with the highest productivity or invalids of World War II), those who fall within the class may be given priority in making a claim, "provided the enterprise possesses the space." Pasherstnik, op. cit. supra note 28, at 53-54. 
contract within the continuum of planning has been described as "the best combination of the plan and khozraschet" (business-accountancy). ${ }^{{ }^{38}}$ This is the amalgam of plan and contract which Pashukanis could not foresee. Wage funds and funds other than wages (housing, medical care, etc.), which constitute the so-called "socialized wage," "r39 are now distributed at the enterprise level by the mechanism of contract.

The obligations of the factory-committee are chiefly ethical. They have a legal character only when the obligation is fixed by legislation, such as control over communal-feeding. But only ethical sanctions may be imposed on the factory-committee for violation of its obligations.

The obligations of workers of the enterprise are also chiefly ethical in nature, such as the obligations to "best use the working day" and to carefully treat the equipment and materials of the enterprise as "sacred socialist property." Nonfulfillment of such obligations by workers gives rise to legal consequences only in cases where violation of the collective agreement is at the same time an infringement of a legal norm. Criminal punishment for absenteeism (progul) follows, not because the worker has violated an obligation in the collective agreement to give a full measure of his working day, but because he has infringed a governmental decree. ${ }^{14^{\circ}}$ Such a decree is operative only when the worker is not an independent contractor but has concluded an employment contract with the enterprise. The civil-law relation ${ }^{14 x}$ should be distinguished from the employment contract because the distinction may determine whether or not criminal penalties will be imposed. Soviet courts have shown themselves astute in seeing through pseudo-employment contracts. ${ }^{x / 2}$

${ }_{238}^{8}$ Agarkov and Genkin (eds.), op. cit. supra note Ir6, Vol. I, at 3 or.

${ }^{239}$ Hubbard, op. cit. supra note 7 , at 192 et seq.; Haensel, A Survey of Soviet Labor Legislation: I9I7-I94I, 36 Ill. L. Rev. 529, 536 et seq. (I942).

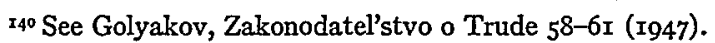

${ }^{14 x}$ The practical significance of this distinction is that not legislation or other normative acts apply, but norms of the Civil Code on obligations in general (GR RSFSR Arts. Io6-29), on contractual obligations in particular (GK RSFSR Arts. I3O-5I) and on the contract of independent contracting in detail (GK RSFSR Arts. 220-35). GK RSFSR Art. 220: "By the contract of independent contracting [podryad, the Roman locatio-conductio operis], one party (the independent contractor) [podryadchik, conductor] undertakes at his own risk to fulfill a specific task at the order of the other party (the one who has given the order) [zakazchik, locator], and the latter undertakes to pay compensation for the completion of the task."

${ }^{142}$ In I940 one $R$ was sentenced by a lower court according to the Decree of 26 June $194^{\circ}$, for absenteeism. The Railroad College of the Supreme Court of the USSR explained that according to his contract with Uchdorstroi, $\mathrm{R}$ was obliged to complete work in the transportation of loads, payment being made upon presentation of R's bills. It was held that since there was no employment contract $R$ could not be held criminally responsible for absenteeism. But on the other hand take the case of S. In I940, S who worked as an accountant for the Zemechinskii section of the cinema-fixing industry and was sentenced for absenteeism. The intermediate court terminated the case on the ground that $S$ was not a member of the Zemechinskii section 


\section{SETTLEMENT OF LABOR DISPUTES}

In Soviet law a labor dispute between workers and the management of an enterprise concerns either the establishment or the application of labor conditions. ${ }^{{ }^{143}}$ Disputes over the application of labor conditions may be cast in the form of a suit, while disputes over the establishment of labor conditions may not.

During the NEP labor disputes based on the establishment of labor conditions arose out of the conclusion of collective agreements. But today such disputes arise only out of questions which have not been exhaustively treated by legislation and are still settled either by collective agreements or by agreement between management and the individual worker or trade union.

Disputes based on the application of labor conditions embrace a variety of claims. A worker may demand wages for work done, or he may question the legality of his dismissal and seek wages for the period in which he would have been employed. The management may claim a fine for violation of the rules of employment or for damage done to the property of the enterprise by the worker.

The method of settlement of labor disputes is regulated by the KZoT of the Union-Republics and by special decrees such as that of August 29, I928. ${ }^{x 4}$ The nature of a labor dispute determines whether it will be heard by the Appraisement and Disputes Commission, the courts, or in certain cases by higher administrative organs.

I. The Appraisement and Disputes Commission ( $R K K) .{ }^{x 45}$-Disputes which may be cast in the form of a suit are divided into two groups. One

and performed work according to special agreements in which it was stipulated that $S$ did not have definite working days, i.e., no employment contract existed. The Judicial College for Criminal Cases of the Supreme Court of the USSR although holding that S could not be convicted under the Decree of 26 June I940, raised the question of the legality of such an agreement by which permanent work as an accountant with a definitely agreed monthly wage did not require regular hours. The agreement was obviously an attempt to evade the laws regulating discipline in state agencies and the Court referred the questions of nullifying such an agreement and of the responsibility of the manager who concluded it to the appropriate union. Aleksandrov, Sovetskoe Trudovoe Pravo 83-85 ( $(947)$.

${ }^{x_{43}}$ Representatives of the trade union not only have the right to act in court in the interest of a particular member of the union but they may also bring suits for members of the trade union. Representatives of the trade union only need authority from the worker immediately interested for termination of a suit, for the transfer of authority to another representative, or to receive money or property, in conformity with Articles $x 7$ and 18 of the Grazhdanskii Protsessual'nyi Kodeks [Civil Procedure Code] (hereafter, GPK) RSFSR.

${ }^{144}$ SZ USSR [1928] No. 56, Art. 495.

${ }^{2} 45$ Rastsenochno-konfliktnaya komissiya. KZoT RSFSR Art. I70. As the name implies, the commission once had the task of piecework appraisement. 
group is subject to mandatory preliminary ${ }^{\mathrm{r} 4^{6}}$ consideration by the $\mathrm{RKK}$, and covers a majority of disputes based on the application of labor conditions. ${ }^{147}$ The other group may be submitted either to the RKK or to the People's Court, the court of first instance in the Soviet judicial system.

The Decree of August 29, I928 gives jurisdiction to the RKK over a number of questions on the establishment of labor conditions, such as the authorization of standards of output and piecework appraisement. This jurisdiction has been narrowed, however, and a Decree of the VTsSPS has recognized that it is incorrect for the RKK to deal with standards of output and appraisements fixed by the management. ${ }^{14^{8}}$ In addition to hearing

${ }_{146}$ Disputes which may be cast in the form of a suit subject to the obligatory preliminary investigation of the RKK, include questions of: $\mathrm{r}$ ) transfer to other work (irrespective of the amount of payment) and maintenance of wages in connection with the transfer; 2) payments for nonfulfillment of standards and payment for spoilage; 3) dismissal for unfitness or for nonfulfillment of obligations; 4) compensation for use of instruments which belong to the worker; 5) the issue of special clothing and special food and in appropriate cases payment of money compensation for them, application of a shortened work day and increased vacations; 6) payments to a substitute for the completion of work of a different qualification; 7) payment for time lost in stoppage; 8) payment for preparation of a piecework job; 9) payment for incompleted piecework; Io) deductions from wages of workers for damage caused by them to the employer in the fulfillment of employment obligations-in all cases, for which legislation establishes a limited measure of responsibility and for which the judicial method of hearing the case has not been introduced exclusively; Ir) payment for time lost in changing jobs; I2) money compensation for ungranted vacation; 13) the amount of payment during probation; I4) the amount of premiums due to the worker; I5) payment for overtime work; I6) satisfaction of the living needs of workers in connection with the nonfulfillment of obligations in the contract of employment. Golyakov, Zakonodatel'stvo o Trude 247-48 (r947).

${ }^{4} 47$ The RKK does not have jurisdiction over: I) cases on the dismissal from or restoration to their jobs of persons who exercise the right of hire and dismissal, and also responsible workers belonging to categories indicated in lists added to the decree of the NKT, I8 October I929; 2) cases on the dismissal from or restoration to their jobs of persons dismissed on the basis of the order of the Minister of State Control on the elimination of jobs (KZoT RSFSR Art. 49); 3) cases of the breach of employment contracts at the demand of the trade union (KZoT RSFSR Art. 49); 4) questions concerning the change of official salaries established by state regulation of wages, and also personal salaries; 5) questions concerning the establishment or change of the number of workers; 6 ) disputes between workers and the management on the basis of distribution of housing facilities, satisfaction of living needs of workers, etc., which do not derive from obligations in the contract of employment; 7) labor cases either decided by or pending in the People's Court; 8) cases on disciplinary fines imposed by higher organs; 9) disputes which may be cast in the form of a suit concerning workers and employees engaged in enterprises, agencies, and businesses, in which there are no members of the trade union; in particular, disputes concerning workers and employees-individual workers who are not members of the trade union. Disputes concerning the first three categories are submitted to higher organs. Ibid., at 248 .

${ }_{148}^{8}$ Decree of the SNK of the USSR, I4 January I939, SP USSR [I939] No. 7, Art. 38. General orders of the revision of standards of output in all central departments of a given ministry are published jointly by the minister and VTSSPS. On the basis of such an order the heads of the central departments jointly with the representative of the central committee of the appropriate trade union publish orders on the revision of standards of output for individual enterprises. In enterprises new standards of output are affirmed by the director upon offering them to heads of shops. Immediately after affirmation the new standards of output enter into force and are brought to the attention of the workers. 
disputes on the application of labor conditions the RKK today has jurisdiction over disputes on the establishment of labor conditions still remaining for determination in the collective agreement. All disputes are settled by agreement between the representatives of management and the factory committee which make up the RKK in each enterprise.

In the absence of agreement over a dispute concerning the application of labor conditions, or when such a dispute has been reversed on appeal as a matter of supervision, the dispute is transferred to the People's Court. Settlements in the RKK are otherwise final and do not need affirmation by any other body. In disputes involving the establishment of labor conditions when there is no agreement in the $R K K$ or the settlement has been reversed on appeal as a matter of supervision, the dispute is transferred for consideration by higher economic and trade-union organizations. Formerly, in such situations the dispute was transferred to arbitration boards or conciliation commissions. ${ }^{\mathrm{T}} 4 \mathrm{9}$

A worker who is dissatisfied with the settlement in the RKK, or the management of an enterprise which does not agree with the settlement accepted by its representatives, may appeal the settlement only as a matter of supervision. This supervision is exercised by the trade unions since the functions of the NKT were transferred to the VTsSPS.

In specified cases ${ }^{150}$ higher trade-union organs may either reverse the settlement, or reject the appeal. When reversed, the settlement is remanded by the higher organ to the same RKK or to a People's Court. Unlike decisions of the RKK, decisions of the higher organs never obligate the management to pay a particular sum or do something specific on behalf of a worker.

Settlements of the RKK and decisions of trade-union organs may be

${ }^{49}$ Arbitration boards and conciliation commissions were formerly set up when necessary in organs of the People's Commissariat of Labor. See Stopani, Praktika NKT SSSR i RSFSR po nadzory za zakonnost'yu koldogovorov i reshenii primiritel'no-treteiskikh organov [Practice of the NKT of the USSR and of the RSFSR in supervision of the legality of collective agreements and settlements of arbitral-conciliation organs] (I928). After the assimilation of the NK'T into the VTsSPS these boards and commissions were set up in trade-union soviets. In I937, however, the boards, commissions, and trade-union soviets ceased to exist.

${ }^{150} \mathrm{~A}$ settlement of the RKK may be reversed by a higher trade-union organ in cases of: I) worsening of conditions of labor in comparison with legislation or contract; 2) exceeding the maximum norms established by legislation or contract; 3 ) violation of the rules on the organization and limits of the jurisdiction of the RKK and the manner of carrying out its work, if this violation substantially affected the decision; 4) falsification of documents or falsity of testimony upon which the settlement is based, if these circumstances have been established by a judicial sentence or judicial decision or any other incontrovertible evidences; 5) discovery of circumstances which were unknown by the RKK in the settlement of the dispute and which have essential bearing on the correctness of the settlement; 6) decision of the dispute which is being investigated by another court. Golyakov, Zakonodatel'stvo o Trude 254 (I947). 
protested $^{\mathrm{x} 5 \mathrm{x}}$ to a higher organ of the trade union by the Procurator of the USSR. In practice the Procurator and his staff have given settlements of the RKK little attention. In 1938 , the Procurator of the USSR ordered his staff to protest settlements of the RKK and decisions of trade-union committees if such settlements and decisions appear clearly illegal or violate substantially the interests of workers or the state.

If the management refuses to comply with an order of the RKK, the complainant may obtain a special certificate ${ }^{\mathrm{IS2}}$ from higher territorial committees of the trade union. In issuing such a certificate the committee checks the legality of the RKK settlement, and in appropriate instances advises the Procurator to institute criminal prosecution against the delinquent members of the managerial staff. If the settlement in the RKK involves a sum certain a form of certificate which has the force of a writ of execution is issued. If a sum certain is not involved, an alternative form of certificate is issued, and the complainant turns to the People's Court for the sole purpose of ascertaining the exact sum.

2. Judicial investigation of labor disputes.- The Law on the Judicial System of 1938 gives the People's Court jurisdiction over civil cases involving ". . . claims in connection with violations of labor legislation." "153 Disputes over the application of labor conditions which are subject to the jurisdiction of the People's Court are: I) disputes which are not subject to the compulsory consideration of the RKK, 2) disputes which have not been settled in the RKK because of disagreement, including questions subject to the preliminary compulsory consideration of the $R K K, 3$ ) disputes which have been decided by the RKK, but the settlement has been reversed on appeal as a matter of supervision. The People's Court does not have jurisdiction over disagreements pertaining to the establishment of labor conditions.

The higher court may r) reject the appeal of the parties or the protest of the procurator, 2) reverse and remand the decision of the People's Court, 3) render a decision on the merits ${ }^{154}$ in certain instances, or 4) dismiss the case.

${ }^{151}$ Rules of 29 August I928 Art. 45 (KZoT RSFSR, Supp. to c. XVI). SZ USSR [x928] No. 56, Art. 495 .

${ }_{152}$ These forms are given in Kiselev and Malkin, Sbornik Vazhneishikh Postanovlenii po Trudu [Collection of the most important decrees on labor] 3I8-I9 (1936).

${ }_{553}$ Law on the judicial system of the USSR, Union and Autonomous Republics Art. 21(b), note 88 supra.

154 The higher court may render a decision on the merits without remanding it for new consideration by the People's Court in cases of: $I$ ) a sufficiently clear factual situation; 2) necessity of changing only the grounds of the decision (reference to legislation, etc.);3) violation by the People's Court in its second consideration of the case, of instructions of the court of appeal given by it in reversing the first decision of the People's Court in the particular case. GPK RSFSR Art. 246(a). 
The procedure in labor cases in the People's Court is controlled by the Code of Civil Procedure of the RSFSR and other Union-Republics. ${ }^{155}$

\section{SOCIALISM AND COMMUNISM}

The principle applied today in the Soviet Union is that of socialism: "From each according to his ability, to each according to his work." Payments are made in accordance with the quantity and quality of work, and the Soviet worker is exposed to a multitude of material and moral ${ }^{15^{6}}$ incentives to increase the productivity of his labor.

But Soviet theory still envisions the eventual transition from socialism to communism, and to the principle: "[F]rom each according to his ability, to each according to his need." In the future communistic society people will not work for compensation, but because of a conviction that work is a necessity for the social good and because work is a need of the healthy human organism. The state and law will "wither away" under favorable economic, cultural, and world conditions. ${ }^{157}$

${ }^{155}$ Suits are brought in conformity with the general rule on jurisdiction in civil cases, i.e., the domicile of the defendant. Plaintiffs in labor cases are exempt from the payment of state fees and other court expenses. GPK RSFSR Art. 43(a). A written declaration is not obligatory. GPK RSFSR Arts. 75, 77. The right to bring suit and also to act as the representative of workers and employees is given to trade unions. KZoT RSFSR Art. I5I. In cases requiring the protection of interests of the state or rights of workers, the court may consider it necessary for the Procurator to participate. GPK RSFSR Art. I2. The court must consider a labor case not later than five days from the commencement of the suit. GPK RSFSR Art. 53(a). A decision of the court in favor of a worker in an amount not higher than a month's earnings is subject to immediate execution. Decisions in favor of the worker in an amount higher than a month's wages are subject to immediate execution in the amount of a month's wages. Decisions of the People's Court may be appealed by the parties or protested by the Procurator as a matter of cassation to higher courts within a ten to fifteen day period. A decision once having entered into effect may be protested as a matter of supervision only by the Chief Procurator of the USSR or Procurator of the Union Republic, Chairman of the Supreme Court of the USSR, and the Presidents of the Supreme Court of the Union Republics to the proper Supreme Court.

${ }^{756}$ In September 1947 the Presidium of the Supreme Soviet of the USSR published a decree on the establishment of the medal "For Reconstruction of the Don Basin," and on the establishment of a yearly holiday, "Day of the Miner," and on the introduction of personal honors for leaders and technical personnel of the coal industry. Pasherstnik, $K$ Tridtsatiletyn Sovetskogo Trudovogo Prava [The Thirtieth Year of Soviet Labor Lavo] Io Sovetskoe Gosudarstvo i Pravo 78, 84-85 (1947).

${ }^{257}$ "Stalin teaches that "the withering away of the state will not come through a weakening of State authority but through its maximum intensification, which is necessary to destroy the remnants of the dying classes and to organize defense against capitalistic encirclement, which is now far from being-and will not soon be-destroyed.' Every other interpretation of the withering away of the state under present conditions is merely an attempt to disarm the proletariat, to weaken the power of the proletarian state and the dictatorship of the proletariatattempts to justify the counterrevolutionary theory of extinction of the class struggle.... Constantly by reinforcing the socialist state and law by every means, shattering one after another all the machinations of the enemies of the people, the enemies of socialism, and developing socialist democracy and culture, the toilers of our country will guarantee the building of the communistic society and the triumph of communism." Vyshinskii, op. cit. supra note 60 , at $64-65$ (Babb, at 62$)$. 
Labor relations under communism will be regulated therefore not by rules of law, but rules of communistic ${ }^{158}$ morals which have become custom, a situation not unlike that in society before the development of the state.

In contrast to the folklore, however, present realities today in the Soviet Union reveal an elaborate body of legal regulation of labor. Soviet labor law serves as "the regulator of the amount of labor and compensation for labor in the Soviet society." "r59 The existence of these rules of law is explained dialectically as necessary to establish the economic and cultural premises for the communistic society. Communism will require a plethora of goods and therefore socialist law aims at increasing the productivity of workers. Communism will also require the reeducation of the Soviet people; socialist law therefore aims at eliminating capitalistic attitudes on the part of workers who do not maintain "labor discipline" and managers who are guilty of "bureaucratic abuses."

\section{CONCLUSION}

With the restoration of orthodox legal values the new Soviet jurisprudence finds in law an important instrumentality of the socialist state. The old wine, however, has been put into new bottles. Insight into the problem of adapting traditional legal values to the process of national-economic planning is obtained from the work of Soviet jurists who today are drafting federal $\operatorname{codes}^{\mathrm{I} 60}$ to supplant the various Union-Republic codes promulgated during the NEP. These jurists are faced with the severe problem (to which Pashukanis had one solution) of reconciling civil-law notions of the Continent with state socialist property and the omnipotency of the plan. The transfer of planned goods between industrial enterprises is effected through "contracts of sale" which carry out the planning obligations of these enterprises. But such "contracts of sale" have little in common with their counterparts in non-Soviet legal systems, ${ }^{x \mathbf{r}}$ and are based on the planning and administrative acts of governmental organs.

The collective agreement shares this development: the obligations of the enterprise towards workers are also a means of carrying out the plan

${ }^{{ }^{88}}$ Aleksandrov, Sovetskoe Trudovoe Pravo II (I947).

159 Ibid., at 12.

${ }^{160}$ See Hazard, op. cit. supra note IIg.

${ }^{16 \mathrm{x}}$ Compare Stuchka's remark that the "contract of sale and purchase is a bourgeois institution, and socialism will never know sale and purchase" (Vyshinskii, op. cit. supra note 62, at I2) and Shkundin, Vliyanie Plana na Obyazatel'stvo [The Infuence of the Plan on Obligation], 2 Sovetskoe Gosudarstvo i Pravo 34 (I947). See also Berman, Commercial Contracts in Soviet Law, 35 Calif. L. Rev. rgr (I947). 
obligations of enterprises and the mechanism by which wages and the "socialized wage" are distributed. We have seen that the collective agreement during the NEP played a significant role in the definition of labor conditions. Having surrendered its normative part to governmental regulation, the collective agreement no longer is an important source of labor law. For the contemporary Soviet jurist, the collective agreement functions as a system of legal obligations of the enterprise and moral obligations of the workers directed toward the fulfillment of the national-economic plan. ${ }^{162}$

${ }^{162}$ The XVII Plenum of the VTsSPS, 25 December I947, reported, "The conclusion of the collective agreements brought about a new increase in socialist emulation, aided the development of mass invention and rationalization. On the basis of obligations in collective agreements there was carried out a revision of obsolete norms of output in machine-construction enterprises, and in mechanical shops, as a result of which the productivity of workers increased. Wages also increased with productivity of labor. In 1947, II million square meters of housing space were constructed and put into use, the number of workers resting and being cared for in rest-homes and sanitaria increased, and the network of clubs, red-corners, libraries, and radio-groups was expanded. Pasherstnik, op. cit. supra note 28 , at 38-39. 